\title{
Impacts of forest management and habitat change on declining avian species in West Virginia
}

Christina Slover

Follow this and additional works at: https://researchrepository.wvu.edu/etd

\section{Recommended Citation}

Slover, Christina, "Impacts of forest management and habitat change on declining avian species in West Virginia" (2015). Graduate Theses, Dissertations, and Problem Reports. 6657.

https://researchrepository.wvu.edu/etd/6657

This Thesis is protected by copyright and/or related rights. It has been brought to you by the The Research Repository @ WVU with permission from the rights-holder(s). You are free to use this Thesis in any way that is permitted by the copyright and related rights legislation that applies to your use. For other uses you must obtain permission from the rights-holder(s) directly, unless additional rights are indicated by a Creative Commons license in the record and/ or on the work itself. This Thesis has been accepted for inclusion in WVU Graduate Theses, Dissertations, and Problem Reports collection by an authorized administrator of The Research Repository @ WVU. For more information, please contact researchrepository@mail.wvu.edu. 


\author{
Christina Slover
}

Thesis submitted to the Davis College of Agriculture, Natural Resources, and Design at West Virginia University in partial fulfillment of the requirements for the degree of

Master of Science

in

Wildlife and Fisheries Resources

Petra Wood Ph.D., Chair

Todd Katzner Ph.D.

John Edwards Ph.D.

Scott Stoleson Ph.D.

School of Forestry and Natural Resources

Morgantown, West Virginia

2015

Keywords: avian abundance; eastern whip-poor-will; forest management; Monongahela National Forest; occupancy modeling; prescribed fire 


\section{Abstract \\ IMPACTS OF FOREST MANAGEMENT AND HABITAT CHANGE ON DECLINING AVIAN SPECIES IN WEST VIRGINIA}

\section{Christina Slover}

Understanding the impacts of forest management and severe storms on avian communities can assist decision making for specific wildlife and timber management goals. This is important because even carefully managed forests will be influenced by a combination of anthropogenic activities and non-anthropogenic forces. I studied the effects of prescribed burning and severe storm events on vegetation structure and avian community diversity and structure in the Monongahela National Forest in central West Virginia. I observed dramatic responses from vegetation structure to prescribed burning but few changes in avian abundances. I measured further impacts, particularly understory vegetation structure, in our forest stands after the occurrence of two severe storms. I also was able to measure a greater response by my aerial insectivore species to the combination of management and storm impacts. My results suggested that infrequent low-intensity prescribed burning did not cause dramatic changes to avian abundance. However, when severe storm impacts were added to the management regime, the impacts to vegetation became consequential enough that high priority and aerial insectivore bird species were also impacted.

Populations of the eastern whip-poor-will (Antrostomus vociferus) are declining due to a range of potential factors including habitat loss, pesticide use and predation. However, because this species is nocturnal, it is poorly studied and neither its ecology nor its demographic status are well measured by traditional bird surveys like the Christmas Bird Count, Breeding Bird Surveys, and point count surveys. Therefore, I studied habitat associations and distribution of eastern whip-poor-wills, to better understand and contextualize their population status and to provide a framework for future research and management. Transect data were analyzed with occupancy models to associate presence of whip-poor-wills with habitat characteristics. I observed habitat associations of and annual differences in both presence and density of whippoor-wills. Whip-poor-wills most frequently occupied areas lower in elevation and mixed forest, herbaceous, as well as wetland cover types. In contrast, high elevation evergreen forest communities had substantially fewer whip-poor-wills. My results suggest that recent recovery of agricultural fields and clearings to forested habitat may be contributing factors to whip-poor-will declines. 


\section{DEDICATION}

I dedicate this thesis to my late grandfather Merlin Slover. His love of hunting and the outdoors inspired my curiosity. 


\section{ACKNOWLEDGMENTS}

I would like to thank Todd Katzner, for continually encouraging and believing in me. I could not have asked for a better mentor throughout this experience. Thank you to my committee members Dr. Petra Bohall Wood, Dr. John Edwards, and Dr. Scott Stoleson. Your thoughtful suggestions and careful guidance have certainly helped to improve my writing. A big thank you goes out to Dr. Thomas Schuler as well as other employees of the USFS Northern Research Station for housing me and my technicians throughout our field seasons and providing much needed advice.

Justin Phillips and Kelsey Pangman were wonderful technicians who were always ready to learn and work hard in the field. I am so fortunate to have had their help with data collection. I also have to acknowledge all of the wonderful staff and fellow graduate students at WVU that have helped to make my time here so enjoyable. You have all become like family to me. Last of all I may have never discovered my passion for birds without my father and mother teaching me how to use a bird guide at a very young age. 


\section{TABLE OF CONTENTS}

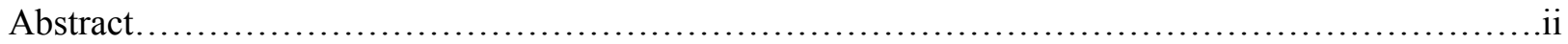

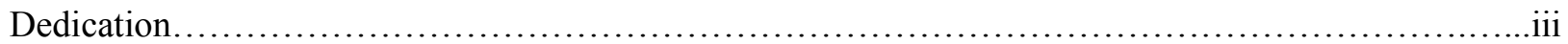

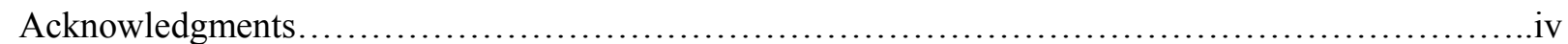

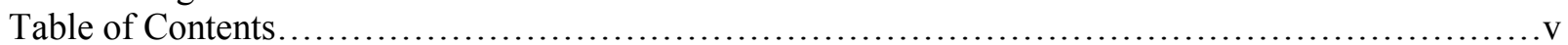

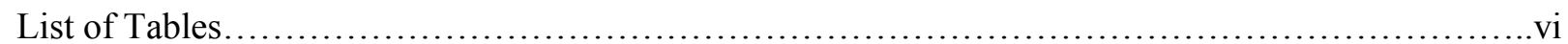

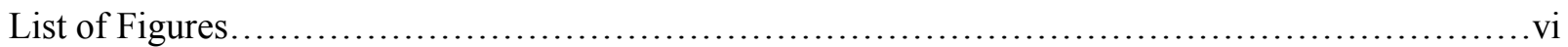

List of Appendices.................................................................. vii

Chapter 1: Interacting Effects of Prescribed Burning and Severe Storms on Vegetation and Birds of Conservation Concern in West Virginia

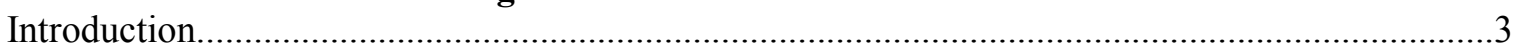

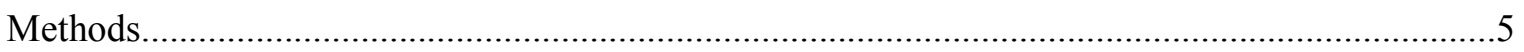

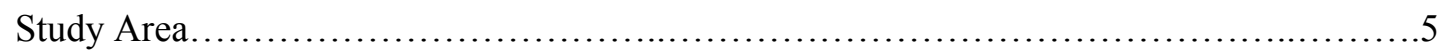

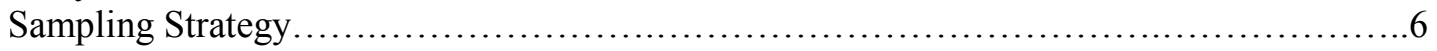

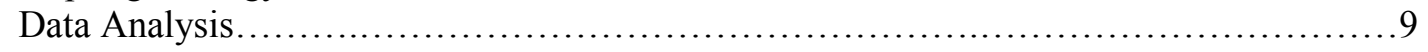

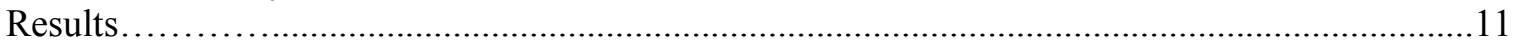

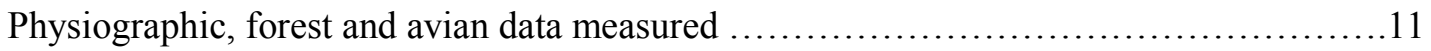

Forest response to management and severe storms.................................. 12

Avian response to management and severe storms ..................................... 12

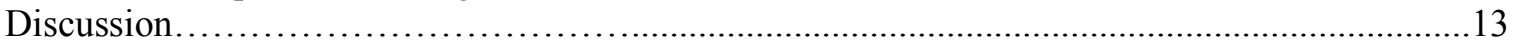

Impacts of Prescribed Burning on Vegetation and Avian Distribution and Density .........14

Interacting Effects of Severe Storms on Vegetation and Avian Abundance ................16

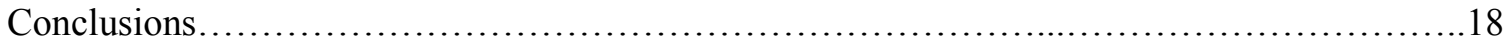

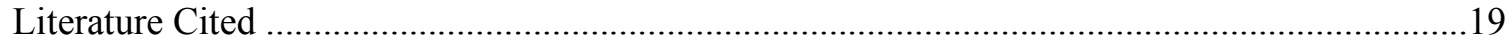

Chapter 2: Whip-poor-wills are Negatively Associated with High Elevation and Highly Fragmented Landscape in Rural West Virginia

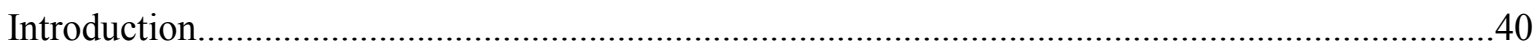

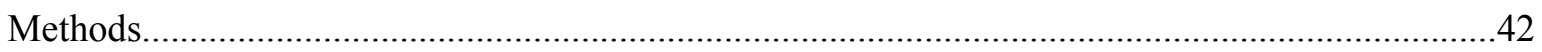

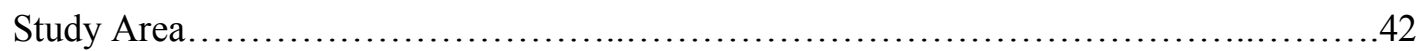

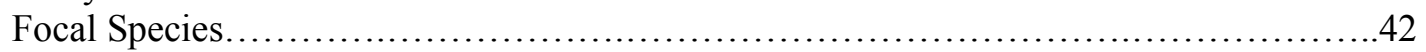

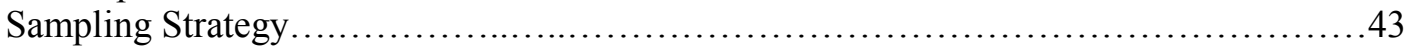

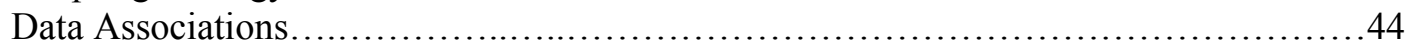

Statistical Analysis-Occupancy Modeling........................................ 45

Statistical Analysis-Modeling Whip-poor-will Occupancy ......................... 47

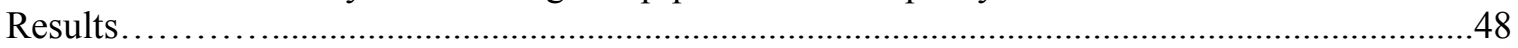

Scale and Landscape Associations............................................ 48

Distribution of Whip-poor-will within the Monongahela National Forest................49

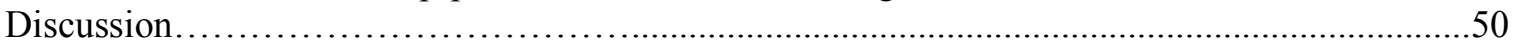

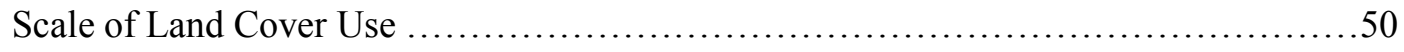

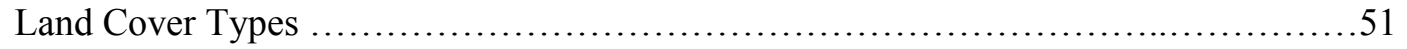

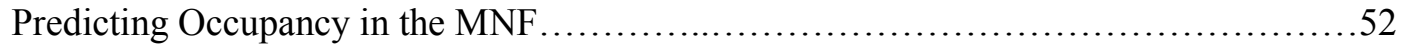

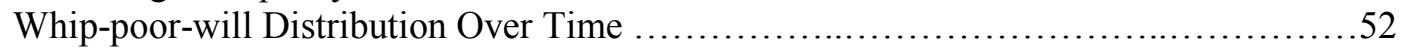

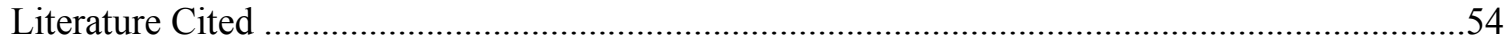




\section{CHAPTER 1:}

\section{LIST OF TABLES}

Table 1. Mean $( \pm \mathrm{SE})$ vegetation characteristics measured at sampling sites in 2012 and 2013 in in burned ( $n=6$ stands, 18 points in 2012, 22 points in 2013), burned and managed $(n=3,6)$, and unburned stands $(n=6,22)$ within $M N F$ .27

Table 2. Mean $( \pm$ SE) number of birds detected at point counts in 2012 and 2013 in burned $(n=6$ stands, 22 points in both years), burned and managed $(n=3,6)$, and unburned stands $(n=6,22)$ in the MNF. .28

\section{CHAPTER 2:}

Table 1. Examples of the global models for each buffer distance. QAIC scores are given. The lowest QAIC score indicates the model with the best fit .58

Table 2. Description of the site and sampling covariates used in Table 1 models. The site covariates were used to estimate of probability of occupancy while the sampling covariates were used to estimate probability of detection at locations in Monongahela National Forest (MNF) study area in eastern West Virginia. Program PRESENCE calculated $\beta$ values for each covariate which was then used to help determine percent occupancy and detection given that covariate.. .59

Table 3. Model averaged estimates for occupancy, colonization, emigration, and detection probabilities .60

\section{CHAPTER 1:}

\section{LIST OF FIGURES}

Figure 1. Point count locations $(\mathrm{n}=70)$ within the MNF .29

Figure 2.Vegetation parameters (mean \pm SE) measured at 50 plots of 0.04 ha within the Monongahela National Forest in 2012 and 2013 30

Figure 3. Abundance (mean $\pm \mathrm{SE}$ ) of focal bird species measured at 50 plots within the Monongahela National Forest in 2012 and 2013. .32

\section{CHAPTER 2:}

Figure 1. Road transect locations in the MNF $(n=10)$ 61

Figure 2. Map of eastern whip-poor-will probability of occupancy. 


\section{LIST OF APPENDICES}

Appendix A.1. Stands sampled in the Monongahela National Forest of West Virginia for vegetation and birds in 2012 and 2013. .34

Appendix B.1. Total count of avian species detected over all three surveys at 50 points in the Monongahela National Forest in 2012 and 2013. . .36

Appendix A.2. Study's classifications of land cover based on 2006 USGS land cover classifications. .64 


\section{Chapter 1}

\section{INTERACTING EFFECTS OF PRESCRIBED BURNING AND SEVERE STORMS ON VEGETATION AND BIRDS OF CONSERVATION CONCERN IN WEST VIRGINIA}

Formatted in the style of Journal of Forest Ecology and Management 


\begin{abstract}
Understanding the impacts of forest management and climate change on avian communities can assist decision making for specific wildlife and timber management goals. This is important because even carefully managed forests will be influenced by a combination of anthropogenic activities and non-anthropogenic forces. We studied the effects of prescribed burning and severe storm events on vegetation structure and avian community diversity and structure in the Monongahela National Forest in central West Virginia. We observed dramatic responses of vegetation structure to prescribed burning but few changes in avian abundances. We measured further impacts, particularly understory vegetation structure, in our forest stands after the occurrence of two severe storms. We also were able to measure a greater response by aerial insectivore species to the combination of management and storm impacts. Our results suggested that infrequent low-intensity prescribed burning did not change avian abundance. However, when severe storms impacts were combined with the management impacts the effect on vegetation became consequential enough that high priority and aerial insectivore bird species were also affected.
\end{abstract}

Keywords: Migratory birds, Prescribed burning, Severe storms 


\section{Introduction}

Prescribed burning is increasingly used for management of early successional habitats (Yeiser et al., 2015, Ward, 2015). However, in northeastern North America the consequences of burning on avian communities are poorly understood. This lack of knowledge is of concern because bird communities are often used as indicators of biodiversity and overall health of ecosystems (Hart et al., 2012). In addition, in an era of increasing climate variability (Marcott et al., 2013) it is critical to understand how fire interacts with climate events to shape ecosystem health.

When fire moves through a landscape, its impacts can range from minor to severe. This variety comes as a result of changes in a fire's intensity over the landscape (Kozlowski and Ahlgren, 1974). Low-intensity fires can have subtle impacts on vegetation structure while high intensity fires have an immediate and larger impact on vegetation structure (Greenberg et al., 2013). The level of impact of fire is important because presence and abundance of many forest vertebrates is influenced by variation in vegetation structure; this is especially true for birds (MacArthur and MacArthur, 1961). Thus, when a fire changes vegetation structure, it is reasonable to expect a response in avian community structure.

The role of fire in shaping avian communities is especially important in light of the known interactions among climate change, habitat change and bird communities (Jarzyna et al., 2015). Climate change can impact birds directly, through alteration of weather (e.g., Crick, 2007, Rehfisch et al., 2004) or indirectly through modification to global meteorological processes, such as by altering the frequency of severe storms (Holland, 2007; Simmonds and Keay, 2009; Tang et al., 2013). Severe storms cause widespread change to landscapes - blowing down trees, 
changing succession dynamics, and impacting nutrient flows (Dale et al., 2001) - all of which can have consequences for the vegetation structure that birds encounter.

The objective of this study was to understand the interacting effects of fire and severe storms on avian community structure in central Appalachian forests. This is relevant because many populations of migratory birds presently are facing long-term declines across North America (Ballard et al., 2003, Sauer et al., 2014). The causes of these declines are linked to habitat loss and alteration, predation, pollutants, collisions with human-made structures and climate change (Longcore et al., 2012). We focused our analyses on a subset of "priority land birds" identified by the Appalachian Mountains Joint Venture (AMJV, 2014), those on the Regional Forest Service Sensitive Species list (RFSS; United States Department of Agriculture [USDA], 2015) and aerial insectivores, a group of high conservation concern (Nebel et al., 2010, Hunt, 2013) whose food should be positively impacted by prescribed burning (Hutto, 1995, Greenberg et al., 2007).

We conducted bird surveys in the Monongahela National Forest (MNF) of West Virginia. The MNF is well suited to study of interacting effects of fire and severe storms because (a) it has a prescribed burn plan in which fires are documented (Thomas-Van Gundy et al., 2007; Knapp, 2010); and (b) over the course of our study, this region was hit by two severe storm events in a short time span. The first of these storms, a derecho or straight line windstorm, blew through the state on 29 June 2012 (NOAA, 2012), knocking down trees and creating numerous canopy gaps. Subsequently, Hurricane Sandy (late October 2012) deposited up to $1 \mathrm{~m}$ of heavy wet snow throughout West Virginia, causing extensive changes in forest structure (Murphy, 2013). To understand how interacting fire and severe climate events impacted bird species, we asked (a) what were the independent impacts of prescribed burns on vegetation and on bird distribution 
and density; and (b) how did effects of severe storms interact with those of fire to drive changes in vegetation and avian presence and abundance.

\section{Methods}

\subsection{Study Area}

The MNF stretches across 313, 631 ha within the Central Allegheny Mountain province of the Appalachian Plateau in West Virginia (Fig. 1; Ferguson, 1964). The MNF occurs in the Central Hardwood region of the northeast, the most extensive concentration of deciduous hardwoods in the world (Hicks, 1998). Tree communities within the MNF are stratified with elevation. Oaks are present at the lowest elevations and at successively higher elevations, mixed mesophytic, northern hardwoods, and red spruce (Picea rubens; Thomas-Van Gundy et al., 2007). In total the MNF contains approximately 75 tree species and 225 bird species (United States Department of Agriculture, 2013). Elevation within the MNF ranges from 305-1,482 m above sea level (ASL) and precipitation is variable such that the western side receives about 152 $\mathrm{cm}$ of rain per year while the eastern side receives about $76 \mathrm{~cm} /$ year (United States Department of Agriculture, 2013). The growing season in the MNF is $140-160$ days and average annual temperatures are $4-14^{\circ} \mathrm{C}(\mathrm{McNab}, 1996)$.

Many of our sampling sites were located in the northern part of the MNF, within the well-studied Fernow Experimental Forest (hereafter, "the Fernow") in Tucker County, West Virginia, about $4.8 \mathrm{~km}$ southeast of the town of Parsons (39 $3^{\prime} 15^{\prime \prime} \mathrm{N}, 79^{\circ} 41^{\prime} 15^{\prime \prime} \mathrm{W}$; Fig. 1). The Fernow is topographically rough, with elevation ranges from 530-1,112 meters ASL. Mean annual temperature is $8.9^{\circ} \mathrm{C}$ and precipitation averages around $1,470 \mathrm{~mm}$ per year (Adams et al., 2004). Soils are $\sim 1 \mathrm{~m}$ deep and are generally hard sandstone and shale in the Calvin and Dekalb 
series, except in the southeastern portion of the forest, where soil is Greenbrier Limestone in the Belmont series (Adams et al., 2004). Vegetation is characterized as mixed mesophytic (Braun, 1950), and the growing season stretches from May through October (Pan et al., 1997). The most common tree species in the Fernow include northern red oak (Quercus rubra), chestnut oak ( $Q$. prinus), yellow-poplar (Liriodendron tulipifera), striped maple (Acer pennsylvanicum), black cherry (Prunus serotina), sugar maple (A. saccharum), black birch (Betula lenta), red maple (A. rubrum), and American beech (Fagus grandifolia) (Adams et al., 2004).

\subsection{Sampling Strategy}

\subsubsection{Sampling design}

To investigate the response of vegetation and bird communities to prescribed burning, we sampled vegetation and birds within burned, burned and managed, and unburned forest stands of $>10$ ha in size (Appendix A). To control for time since burning, all stands we classified as burned or burned and managed were sampled 3-6 years after burning (Appendix A). Managed stands had either herbicide or logging treatments. Unburned forests were classified as either midage ( $\sim 40-50$ years old) or mature ( $\sim 80-100$ years old), based on time since treatment (burning, logging, etc.; Appendix A). The different ages of burned and unburned forests complicate interpretation of burning's effects on forest birds (in an ideal world, all stands would be of the same age, although this is difficult since forest age is often equal to time since burning); we discuss these issues when we interpret our results.

We randomly selected 6 burned, 3 burned and managed, and 6 unburned stands from a USFS database of all suitable stands ( $n=26$ burned stands, $n=2968$ unburned stands). Stands were scattered throughout the MNF (Fig 1), with about half of them within the Fernow. 
Within each of the 15 stands, we surveyed at $1-5$ points for vegetation and avian species ( $\mathrm{n}=46$ points total in year 1, 50 points in year $2 ; \mathrm{n}=18$ (in 2012) and 22 (in 2013) in burned stands, 6 points in burned + managed stands, and 22 points in unburned stands). The first severe storm (the derecho) occurred at the end of the 2012 field season. Blowdown was so great from that storm that roads were blocked and we were unable to complete vegetation field sampling at four points in burned stands. Points were located $\geq 250 \mathrm{~m}$ apart from each other and, to eliminate edge effects in avian data, were located $>100 \mathrm{~m}$ from the edge of the stand (Ralph et al., 1995; Baker and Lacki, 1997; Costello et al., 2000; Klaus et al., 2010). At each point we used a GIS (ESRI 2012) to remotely characterize the management type, region, forest type, slope position,

slope, aspect, soil type, and elevation. Classification was based on the following base maps: 2012 WV Ecological Land Units, STATSGO soils data and a USGS 2003 3-meter Digital Elevation Model (all from the West Virginia State GIS Data Clearinghouse, 2014).

\subsubsection{Vegetation sampling}

We measured vegetation in June and July of each year at $0.04 \mathrm{ha}$ circular plots centered on each sample point (James and Shugart, 1970). On each plot, we measured vegetation at the ground, mid- (shrub and understory) and canopy levels. At ground level, we measured percent ground cover (to the nearest 5\%) using a Daubenmire square (Daubenmire, 1959) and we measured leaf litter depth with a ruler. At the mid-level, we measured living understory height (to $5 \mathrm{~m}$ ) to the nearest $0.5 \mathrm{~m}$ by recording contacts along a vegetation pole (Robel et al., 1970) and, to thoroughly understand avian response to low vegetation structure, we measured percent cover (to the nearest $5 \%)$ separately of small $(<0.5 \mathrm{~m})$, medium $(0.5-1.5 \mathrm{~m})$ and tall $(1.5-2.5 \mathrm{~m})$ shrubs. We estimated overstory canopy cover (to the nearest 5\%) using a densiometer (Carpenter et al., 2011). Estimates of percent ground cover, leaf litter depth, understory height and percent 
canopy cover were generated by averaging measurements taken at the center of the plot and at 4 points defined by the cardinal directions and located at the edge of the plot. Shrub cover was estimated at the center of the circular plot. To improve accuracy of visual estimates, each were made separately by two observers and then compared (van Hees et al., 2000)

Within each plot, we counted the numbers of each tree and shrub species present and we used a 10 factor wedge prism to measure stem density of seedlings, saplings, and trees. When a stem was counted as "in” by the prism (van Laar and Akça, 2007), we measured diameter at breast height $(\mathrm{dbh})$ and organized stems into three size classes: seedlings $(\cong 7.6 \mathrm{~cm} \mathrm{dbh})$, saplings (>7.6-22.9 cm dbh) or trees ( $>22.9 \mathrm{~cm}$ dbh; Peet et al., 1998, McDermott et al., 2011).

\subsubsection{Avian sampling}

We used 10-minute point counts to survey the bird community at each sample point annually (Ralph et al., 1995). Point counts were conducted between local sunrise and 10AM between 13 May and 25 July 2012 and 14 May and 25 June 2013. Severe storms did not affect our ability to conduct avian point counts. We recorded all avian species within $50 \mathrm{~m}$ of the point detected by sight or sound (Ralph et al., 1995). In 2012, all data were collected by a single observer. In 2013, surveys were completed by the same observer with assistance from a second observer. Surveys were conducted 2-3 times at each point. We rotated points among the two observers to account for among-observer variability in detection and we rotated starting times to account for variation in initiation of singing by different species (Farnsworth et al., 2002, Farnsworth et al., 2005). 


\subsection{Data Analysis}

West Virginia had two severe storm events between year 1 and year 2 of our study that caused extensive changes to vegetation cover throughout the MNF and the Fernow. Because these storms occurred after the first field season's data were collected and before the second field season, we were able to evaluate the effects of fire on vegetation and birds (within-year 1 comparison; objective 1) and separately look at the effects of severe storms interacting with fire on vegetation and birds (year 1 vs year 2; objective 2). All statistical analyses were conducted within the software JMP® (SAS Institute Inc., 2012)

To understand how vegetation responded to fire and storms, we first asked if we could detect differences in physiographical characteristics (e.g., elevation, which does not change from year to year) among our 15 burned, burned and managed, and unburned forest stands. To test for these differences, we used an ANOVA with management type as a predictor and elevation as a response variable. We log-transformed elevation data to better fit a normal distribution and investigated significant differences $(\alpha<0.05)$ among management types using post-hoc boxplots.

Once we understood the physiographical context of our stands, we then evaluated withinand across-year differences in the vegetative characteristics we averaged across stands. For this analysis we used a series of generalized linear mixed models in which management type (burned, burned and managed, and unburned) was a predictor variable and percent tree canopy cover, percent shrub canopy cover, percent ground cover, understory height, leaf litter depth, and tree size class were response variables (one in each model). We log-transformed data that were not normally distributed and, to look for responses to storms, we used year as a repeated effect in the model. Because we were specifically interested in interactions between management type and storms, we included a year*treatment predictor in the model. When response variables showed 
differences $(\alpha<0.05)$ between management types or when interaction terms were significant, we then investigated those differences through multiple contrasts ("Generalized Linear Model Contrast" in JMP) which produced chi-square statistics.

Prescribed burning is not a commonly used management method within all portions of the MNF. Because of this our sample locations tended to be clustered in either the northern or southern portion of the forest. To understand whether patterns we observed were driven by underlying spatial patterns (i.e. northern data more related to northern data and southern data more related to southern data) in the organization of our sample points, we tested for spatial patterns with a Mantel test (Mantel, 1967).

Finally, to understand the impacts of burning and storms on birds, we evaluated withinand across-year differences in the avian point count data collected at each of the sample points annually. We focused analyses on species of high conservation concern and aerial insectivores (species listed in Appendix B). We built generalized linear mixed models with a Poisson distribution using data for each forest stand in which management type, year and a management*year interaction were predictor variables and in which species abundance was the response variable. We measured abundance within a stand as the average maximum number of individuals of each species recorded at each point within a particular stand during any one field season (Duguay et al., 2001). If species abundances showed differences $(\alpha<0.05)$ in response to predictor variables, we used multiple contrasts, as above, to better evaluate those differences. 


\section{Results}

\subsection{Physiographic, forest and avian data measured}

Because prescribed burning occurs more frequently in the southern portion of the MNF, management of the stands we sampled was not uniform throughout the region. All of our unburned $(n=6)$ and all of the burned and managed $(n=3)$ stands were located in the northern half of the MNF, while all 6 of our burned stands were located in the southern half of the MNF. The unburned stands we sampled were mid-age and mature forest composed of a mixed mesophytic cove type at an average $793 \mathrm{~m}$ elevation. The burned and managed stands were younger stands composed of 50\% northern hardwood and 50\% mixed mesophytic cove forest type at $717 \mathrm{~m}$ elevation. The burned stands also were younger age classes and made up of a variety of forest types, $\sim 25 \%$ pine oak, $10 \%$ mixed mesophytic cove, $40 \%$ oak, and $25 \%$ mixed mesophytic cove and oak at 902m ASL. All stands had roughly similar aspects (mode of burned $=230^{\circ}$, mode of burned $\&$ managed $=245^{\circ}$, mode of unburned $=188^{\circ}$ ) but elevation was different among the three management types $(F=23.4, p<0.001)$.

During surveys we counted a total of 68 different avian species (Appendix B). Eight of those species are considered high priority species by the Appalachian Mountain Joint Venture, 1 as sensitive on RFSS lists, and 6 were considered aerial insectivores. We focused subsequent analyses on the 13 species on these lists (several appear on multiple lists; Table 2). We detected no spatial patterns in our avian abundance data $(2012 \mathrm{r}=0.11 \mathrm{p}=0.14 ; 2013 \mathrm{r}=0.06 \mathrm{p}=0.24)$

\subsection{Forest response to management and severe storms}

Vegetative responses to prescribed burning were largely as one might expect from a severe disturbance such as fire (Table 1). The number of saplings per plot and small shrub cover 
were both greatest in burned plots and least in unburned plots. In contrast, the number of trees, the canopy and tall shrub cover, and the understory height were all greatest in unburned plots. Litter depth was greatest in burned and managed plots.

We also measured responses to severe storm events (a year effect; Table 1, Fig. 2 a- e). The number of seedlings (stems $<7.6 \mathrm{~cm} \mathrm{dbh}$ ) was greater in 2012 , the year before the storms, than after the storms in $2013(1.96 \pm 0.33[ \pm \mathrm{SE}]$ vs. $1.00 \pm 0.16)$; the same was true for percent canopy cover $(0.77 \pm 0.03$ vs. $0.61 \pm 0.03)$. In contrast, litter depth $(1.63 \pm 0.13$ vs $3.38 \pm 0.19)$, small shrub cover $(0.30 \pm 0.03$ vs $0.50 \pm 0.04)$ and medium shrub cover $(0.29 \pm 0.03$ vs $0.42 \pm$ 0.04) were all greater after the storm than before the storm $(2013>2012)$.

Of the variables we measured, only understory height showed a year*treatment interaction effect indicating a response to storms that varied among the different management types (Table 1, Fig 2f). Between 2012 and 2013, understory height decreased in burned and burned and managed stands (chi-square $=5.0, \mathrm{p}=0.03$ and 4.1, $\mathrm{p}=0.04$, respectively) and increased in unburned stands (chi-square $=10.2, \mathrm{p}=0.001)$.

\subsection{Avian response to management and severe storms}

Five of our 13 focal bird species showed a response to management type (Table 2, Fig 3). Of these five, two (black-billed cuckoo and Louisiana waterthrush) were most abundant in burned and managed stands; the cuckoo was not detected in any other management type. Blue headed vireos were most common in unburned stands. Least flycatchers were never counted in unburned stands. Finally, Acadian flycatchers were least common in burned stands. Three of the species that did respond to prescribed burning were aerial insectivores. The species that did not respond to prescribed burning included three aerial insectivores (eastern bluebird, eastern wood- 
pewee, great-crested flycatcher) and several warblers of high priority conservation concern, including the cerulean warbler.

Three of our 13 focal bird species, two of them aerial insectivores, showed a response to the severe storms that hit the MNF between the years of our study (a year effect; Table 2, Fig 3). Acadian flycatchers and Lousiana waterthrush both were more prevalent before the storms than after them $(0.70 \pm 0.12( \pm \mathrm{SE})$ vs. $0.36 \pm 0.11 ; 0.26 \pm 0.06$ vs. $0.08 \pm 0.04$, respectively). In contrast, eastern wood-pewee showed the opposite pattern, they were more prevalent after the storms than they were before them $(1.34 \pm 0.14$ vs. $0.60 \pm 0.11)$.

Three of our 13 focal species, two of them aerial insectivores, showed a different response to storms in the differently managed forest stands (i.e., showed a year*treatment interaction; Table 2, Fig 3). Blue-headed vireo increased in abundance after storms in unburned stands (chi-square stat $=16.6, \mathrm{p}<0.01 ;$ Fig $3 \mathrm{C}$ ). Least flycatcher increased in abundance after storms, but only in burned and managed stands ( $p=0.02$; Fig 3E). Finally, Louisiana waterthrush dramatically decreased after the storms in burned and burned and managed stands (burned: chi-square $=6.9, \mathrm{p}<0.01$; burned $\&$ managed: chi-square $=6.9 \mathrm{p}<0.01$ ) but showed no significant change in unburned stands (Fig 3F). None of the other sensitive species or aerial insectivores showed any response to interacting effects of severe storms and management type.

\section{Discussion}

Wildlife habitat is being increasingly influenced by changes in processes associated with global climate change. Understanding how these changes interact with human-driven habitat management is a key problem in natural systems worldwide. Because our research was conducted before and after two severe storm events that occurred within months of each other, 
we were able to evaluate not only the effects of fire on avian communities, but also the interacting effects of prescribed burning with these exceptional weather events.

\subsection{Impacts of Prescribed Burning on Vegetation and Avian Distribution and Density}

Prescribed burning is used for management of early successional habitat, fuel reduction, oak regeneration, site preparation, and promotes stand reinitiation. The process is seen as a way to increase forage, maintain habitat, and to increase soil nutrient levels (especially phosphorous; Franklin et al.,2003, Rietl and Jackson, 2012). Stands that were burned had fewer larger trees and less canopy cover; presumably this meant that in these stands, more sunlight reached the forest floor. As a consequence, these stands also had more and taller understory saplings and greater small shrub cover.

Because we saw such dramatic responses by vegetation to prescribed burning, we anticipated also detecting differences in abundance of the high priority and aerial insectivore species we surveyed. We particularly expected that the opened canopy and increased perch availability in burned stands would make them more favorable to aerial insectivores. Although we did measure some change in abundance within these groups, these changes were confusingly small, difficult to interpret, and not strongly correlated to presence or absence of burning. In fact, only five of 13 species appeared to show a statistically significant response to management type, such that in unburned stands, two aerial insectivore species (Acadian flycatcher and blue-headed vireo) clearly occurred in higher abundance and one aerial insectivore species (least flycatcher) clearly in lower abundance. Two species (the cuckoo and the waterthrush) were at highest numbers in the two burned and managed stands. The remaining 8 species showed no response to prescribed burning. It appears that habitat preferences overwhelmed any response based on 
foraging guild since Acadian flycatchers and blue-headed vireos are considered closed-canopy obligates while least flycatchers prefer open-canopies (Whitehead and Taylor, 2002, Tarof and Briskie, 2008, Morton and James, 2014).

Although the abundance of our focal species was not clearly tied to the factors driving vegetation variability, several features of our vegetation analysis do help to interpret our withinyear avian point-count data. First, all of the burned sites we evaluated were treated with infrequent, low-intensity burns and had the opportunity to recover, post-fire, for 3-6 years. Thus, although they are all undergoing active management, our research evaluates medium-term postfire consequences of light burning, rather than the immediate ramifications for vegetation and wildlife from potentially hotter fires. Thus, we would not expect to see, nor did we see, a disturbance-mediated response by a post-fire colonist species the eastern bluebird; this pattern is consistent with other studies of low-intensity fires (Greenburg et al., 2007). Second, burned stands we studied were located on average at $\sim 100 \mathrm{~m}$ higher elevation than unburned stands. Elevation can have a profound effect on patterns of avian species abundance (Siegel et al., 2012) and two high priority species - cerulean warbler and Louisiana waterthrush - are not typically found at higher elevations (Mattsson et al., 2009, Buehler et al., 2013). Third, it is possible that underlying spatial patterns influenced the patterns in avian abundance we measured. In particular, our northern survey stands were located in areas that are not fire adapted and burn poorly but our southern stands were more fire adapted and experienced historical 0-35 year fire disturbance regimes (Thomas-Van Gundy et al., 2007). Although we detected no spatial patterns in our data, it is possible that birds in fire adapted habitats may be concurrently more resistant to fire-driven change than those in non-adapted habitats. Some of the management effects we observed could have been influenced by this underlying pattern. 
Finally, of all the focal species we monitored, only the yellow-bellied sap-sucker and the eastern wood-pewee were associated with our younger stands. Likewise, several species of high concern that are associated with gappy forests with medium levels of high canopy cover and mature forest (e.g., cerulean warbler; Buehler et al., 2013) and moderate subcanopy with an open forest floor (e.g. wood thrush; Evans et al., 2011) showed no response to treatment type. If the trends in our data were driven by forest age, we would have expected them to show stronger response to forest management. Since this was not the case, it argues against a simple correspondence between stand age and burn status.

\subsection{Interacting Effects of Severe Storms on Vegetation and Avian Distribution and Density}

Half the vegetative parameters we measured were significantly affected by the severe storms that hit West Virginia in late summer and fall of 2012. The two storms appeared to damage large trees (canopy cover decreased), removed smaller trees (seedlings decreased), increased detritus (litter depth increased) and created gaps for understory plants (small and medium shrub cover increased). Finally, the interacting response of understory height to storms and to management suggests that in areas with fewer large trees, understory plants bear more direct storm impacts.

The effects to plants are largely expected. Likewise, since avian life histories are reliant on vegetation structure, we expected storms to influence patterns in avian abundance and possibly to interact with management to drive distributions. Certainly it was the case that two insectivore species and a species of conservation concern - Acadian flycatchers, eastern woodpewee and Louisiana waterthrush -responded to severe storms (showed a year effect). However, their responses were not identical; the pewee increased after the storms and the flycatcher and 
the waterthrush declined. It again appears that habitat preference overwhelmed any response based on foraging guild since both the Acadian flycatcher and the Louisiana waterthrush are associated with closed canopies, which decreased after the storms and the eastern wood-pewee is associated with open-canopy. Also the Lousiana waterthrush is tied to streams and tends to breed earlier than other avian species, which makes them easy to miss detecting with point count surveys (Mattsson et al., 2009).

Three of our focal species - blue-headed vireo, least flycatcher and the waterthrush - all showed a response to interacting effects of storms and management. Again, their responses were inconsistent, such that the vireo increased after storms in unmanaged stands but decreased in burned and managed stands, the waterthrush decreased after storms in both types of burned areas and did not change in unmanaged stands, and the least flycatcher decreased after storms in burned and managed areas but showed no other responses. Two of these species (the vireo and flycatcher) are aerial insectivores that rely on insects as prey and exposed perches for foraging and this reliance may provide insight into a possible mechanism for their response. Since severe storms increase debris, insect populations may respond positively to storms, thus providing food for these species (Scholwalter, 2012). Likewise, changes in the spatial patterns of canopy openings and perch availability may also influence abundance of aerial insectivores. Finally, waterthrush depend strongly on stretches of streams surrounded by closed canopy forest (Mattsson et al., 2009). Therefore, it is possible that the blowdown and increased debris caused by the combination of storms and management created canopy openings which could make those streams less suitable for this species. 


\subsection{Conclusions}

The occurrence of high severity storms is likely to increase as our climate changes (Tang et al. 2013). When severe storms occur, trees are blown down, succession dynamics altered and nutrient processes changed. Our analyses suggest that despite short-term vegetative changes brought on by severe storms, a relatively small proportion (36\%) of the priority avian species associated with eastern hardwoods showed a response driven either by storms or management. In contrast, a greater proportion of aerial insectivores (4/6) responded to severe storm and management events. Thus, our results suggest that infrequent low-intensity prescribed burning is unlikely to enact dramatic changes in avian species abundance. However, when severe storm effects are combined with management effects, impacts to vegetation can be consequential and high priority and aerial insectivore bird species also are influenced. 


\section{Literature Cited}

Adams, M. B., Loughry, L., \& Plaugher, L. (2004). Experimental Forests and Ranges of the USDA Forest Service. USDA Forest Service. Northeastern Research Station.

Appalachian Mountain Joint Venture (AMJV). 2014. Priority Species. Retrieved February/07, 2015 from amjv.org/documents/Priority_Landbird_Species.pdf

Avery, E. T., \& Burkhart, E. Harold. (2002). Forest Measurements 5th Edition. McGraw-Hill Higher Education, New York, NY.

Ballard, G., Geupel, G. R., Nur, N., \& Gardali, T. (2003). Long-term declines and decadal patterns in population trends of songbirds in western north america, 1979-1999. The Condor, 105(4), 737-755.

Braun, E. L. (1950). Deciduous forests of eastern North America. Philadelphia, PA: Blakiston.

Buehler, David A., Hamel, P.B., \& Boves,T. (2013). Cerulean Warbler (Setophaga cerulea), The Birds of North America Online (A. Poole, Ed.). Ithaca: Cornell Lab of Ornithology; Retrieved from the Birds of North America Online: http://bna.birds.cornell.edu/bna/species/511.doi:10.2173/bna.511.

Carpenter, J. P., Wang, Y., Schweitzer, C., \& Hamel, P. B. (2011). Avian community and microhabitat associations of cerulean warblers in Alabama. The Wilson Journal of Ornithology, 123(2), 206-217.

Crick, H. Q. (2004). The impact of climate change on birds. Ibis, 146(s1), 48-56.

Dale, V. H., Joyce, L. A., McNulty, S., Neilson, R. P., Ayres, M. P., Flannigan, M. D., et al. (2001). Climate change and forest disturbances: Climate change can affect forests by altering the frequency, intensity, duration, and timing of fire, drought, introduced species, 
insect and pathogen outbreaks, hurricanes, windstorms, ice storms, or landslides.

Bioscience, 51(9), 723-734.

Daubenmire, R. (1959). A canopy-coverage method vegetational analysis. Northwest Science, $33,43-64$.

Downing, A. L., \& Leibold, M.A. (2010). Species richness facilitates ecosystem resilience in aquatic food webs. Freshwater Biology, 55(10), 2123-2137.

Duguay, J. P., Wood, P. B., \& Nichols, J. V. (2001). Songbird abundance and avian nest survival rates in forests fragmented by different silvicultural treatments. Conservation Biology, $15(5), 1405-1415$.

Ehrlich, P. R., D. S. Dobkin, \& Wheye, D. (1988) The birder's handbook. Simon and Schuster, New York.

Evans, M., Gow, E., Roth, R.R. , Johnson, M.S., \& Underwood, T.J. (2011). Wood Thrush (Hylocichla mustelina), The Birds of North America Online (A. Poole, Ed.). Ithaca: Cornell Lab of Ornithology; Retrieved from the Birds of North America Online: http://bna.birds.cornell.edu/bna/species/246 doi:10.2173/bna.246

Farnsworth, G. L., Nichols, J. D., Sauer, J. R., Fancy, S. G., Pollock, K. H., Shriner, S. A., et al. (2005). Statistical approaches to the analysis of point count data: A little extra information can go a long way. USDA Forest Service General Technical Report PSWGTR-191,735-743.

Farnsworth, G. L., Pollock, K. H., Nichols, J. D., Simons, T. R., Hines, J. E., Sauer, J. R., et al. (2002). A removal model for estimating detection probabilities from point-count surveys. The Auk, 119(2), 414-425. 
Ferguson, R. H. (1964). The timber resources of West Virginia. Upper Darby, PA: Northeastern Forest Experiment Station, Forest Service, U.S. Dept. of Agriculture.

Franklin, S. B., Robertson, P. A., \& Fralish, J. S. (2003). Prescribed burning effects on upland Quercus forest structure and function. Forest Ecology and Management, 184(1-3), 315335.

Greenberg, C. H., Tomcho, A. L., Lanham, J., Waldrop, T. A., Tomcho, J., Phillips, R. J., et al. (2007). Short $\square$ term effects of fire and other fuel reduction treatments on breeding birds in a southern Appalachian upland hardwood forest. The Journal of Wildlife Management, 71(6), 1906-1916.

Greenberg, C. H., Waldrop, T. A., Tomcho, J., Phillips, R. J., \& Simon, D. (2013). Bird response to fire severity and repeated burning in upland hardwood forest. Forest Ecology and Management, 304, 80-88.

Hart, M., Bush, P., \& Malouin, C. (2012). Indicator guilds representing forest composition and configuration in the Great Lakes - St. Lawrence forest region - A nationally replicable selection methodology. Ecological Indicators, 23(0), 374-383. doi:http://dx.doi.org.www.libproxy.wvu.edu/10.1016/j.ecolind.2012.04.018

Hicks, R. R. (1998). Ecology and management of central hardwood forests. Wiley \& Sons. 432 pp.

NOAA. (2012). Historic "derecho" severe wind event storms across the midwest and midAtlantic on June 29, 2012. Retrieved March /2014, 2014, from http://www.erh.noaa.gov/rnk/events/2012/Jun29_derecho/summary.php Holland, G. (2007). Climate change and extreme weather. IOP Conference Series: Earth and Environmental Science, 6(9). 
Holling, C. S. (1973). Resilience and stability of ecological systems. Annual Review of Ecology and Systematics, 4, 1-23. Retrieved from http://www.jstor.org/stable/2096802

Hunt, P. D. (2013). Habitat Use by the Eastern Whip-poor-will (Antrostomus vocifersus) in New Hampshire: with Recommendations for Management. Report to the New Hampshire Fish and Game Department Nongame and Endangered Wildlife Program. Audubon Society of New Hampshire, Concord.

Hutto, R. L. (1995). Composition of bird communities following stand $\square$ replacement fires in northern Rocky Mountain (USA) conifer forests. Conservation Biology, 9(5), 1041-1058.

James, F. C., \& Shugart Jr, H. H. (1970). A quantitative method of habitat description. Audubon Field Notes, 24(6), 727-736.

Jarzyna, M.A., Porter, W.F., Maurer, B.A., Zuckerberg, B. \& Finley, A.O. (2015). Landscape fragmentation affects responses of avian communities to climate change. Global Change Biology, in press.

Katzner, T.E. \& Parker, K.L.. (1997). Vegetative characteristics and size of home ranges used by pygmy rabbits (Brachylagus idahoensis) during winter in southwestern Wyoming. Journal of Mammalogy, 78(4):1063-1072.

Knapp, E. E. (2010). Ecological effects of prescribed fire season: A literature review and synthesis for managers. CITY, DIANE Publishing.

Kozlowski, T. T., \& Ahlgren, C.E. (2012). Fire and ecosystems. New York, NY: Academic Press.

Longcore, T., Rich, C., Mineau, P., MacDonald, B., Bert, D. G., Sullivan, L. M., et al. (2012). An estimate of avian mortality at communication towers in the United States and Canada. PLoS One, 7(4), e34025. 
Mantel, N. (1967). The detection of disease clustering and a generalized regression approach. Cancer Res. 27, 209 - 220.

Mattsson, B. J., Master T. L., Mulvihill, R.S. \& Robinson, W.D. (2009). Louisiana Waterthrush (Parkesia motacilla), The Birds of North America Online (A. Poole, Ed.). Ithaca: Cornell Lab of Ornithology; Retrieved from the Birds of North America Online: http://bna.birds.cornell.edu/bna/species/151doi:10.2173/bna.151

McDermott, M. E.,Wood, P.B., Miller, G.W., \& Simpson, B.T. (2011). Predicting breeding bird occurrence by stand-and microhabitat-scale features in even-aged stands in the Central Appalachians. Forest Ecology and Management, 261(3), 373-380.

McNab, W.H. 1996. Ecological subregions of the United States. USFS. Available online at: http://www.fs.fed.us/land/pubs/ecoregions/index.html.

MacArthur, R. H., \& MacArthur, J. W. (1961). On bird species diversity. Ecology, 42(3), 594598.

Marcott, S. A., Shakun, J. D., Clark, P. U., \& Mix, A. C. (2013). A reconstruction of regional and global temperature for the past 11,300 years. Science (New York, N.Y.), 339(6124), $1198-1201$.

Morton, E. \& James, R. D. (2014). Blue-headed Vireo (Vireo solitarius), The Birds of North America Online (A. Poole, Ed.). Ithaca: Cornell Lab of Ornithology; Retrieved from the Birds of North America Online: http://bna.birds.cornell.edu/bna/species/379 doi:10.2173/bna.379

Murphy, M. (2013). A quick look back at hurricane sandy in West Virginia. Retrieved March/2014, 2014, from http://blogs.charlestondailymail.com/cityhall/2013/10/30/sandy/ 
Nebel, S., Mills, A., McCracken, J. D., \& Taylor, P. D. (2010). Declines of Aerial Insectivores in North America Follow a Geographic Gradient. Avian Conservation and Ecology, 5(2), 1. Pan, C., Tajchman, S., \& Kochenderfer, J. (1997). Dendroclimatological analysis of major forest species of the central Appalachians. Forest Ecology and Management, 98(1), 77-87.

Peet, R. K., Wentworth, T. R., \& White, P. S. (1998). A flexible, multipurpose method for recording vegetation composition and structure. Castanea, 262-274.

Peterson, G., Allen, C. R., \& Holling, C. S. (1998). Ecological resilience, biodiversity, and scale. Ecosystems, 1(1), 6-18.

Ralph, C. J., Droege, S., \& Sauer, J. R. (1995). Managing and monitoring birds using point counts: Standards and Applications 1, 3.

Rehfisch, M. M., Feare, C. J., Jones, N. V., \& Spray, C. (2004). Climate change and coastal birds. Ibis, 146(s1), 1-1.

Rietl, A. J., \& Jackson, C. R. (2012). Effects of the ecological restoration practices of prescribed burning and mechanical thinning on soil microbial enzyme activities and leaf litter decomposition. Soil Biology and Biochemistry, 50(0), 47-57.

Robel, R.J., Briggs, J.N., Dayton, A.D., \& Hulbert, L.C. (1970). Relationships between visual obstruction measurements and weight of grassland vegetation. Journal of Range Management 23,295-297.

Sandström, U. G., Angelstam, P., \& Mikusiński, G. (2006). Ecological diversity of birds in relation to the structure of urban green space. Landscape and Urban Planning, 77(1-2), $39-53$.

SAS Institute Inc. (2012). Using JMP 10. Cary, NC: SAS Institute Inc. 
Schowalter, T. D. (2012). Insect responses to major landscape-level disturbance. Annual Review of Entomology, 57(1), 1-20.

Siegel, R. B., Wilkerson, R. L., Kuntz, R. C., Saracco, J. F., \& Holmgren, A. L. (2012). Elevation ranges of birds at Mount Rainier National Park, North Cascades National Park Complex, and Olympic National Park, Washington. Northwestern Naturalist, 93(1), 2339.

Simmonds, I., \& Keay, K. (2009). Extraordinary September arctic sea ice reductions and their relationships with storm behavior over 1979-2008. Geophysical Research Letters, 36(19).

Tang, Q., Zhang, X., \& Francis, J. A. (2013). Extreme weather in northern mid-latitudes linked to vanishing cryosphere. Nature Climate Change, 4(1), 45-50.

Tarof, S., \& Briskie J. V. (2008). Least Flycatcher (Empidonax minimus), The Birds of North America Online (A. Poole, Ed.). Ithaca: Cornell Lab of Ornithology; Retrieved from the Birds of North America Online: http://bna.birds.cornell.edu/bna/species/099 doi:10.2173/bna.99.

Thomas-Van Gundy, M. A., Nowacki, G. J., \& Schuler, T. M. (2007). Rule-based mapping of fire-adapted vegetation and fire regimes for the Monongahela national forest. Newtown Square, PA: U.S. Dept. of Agriculture, Forest Service, Northern Research Station.

van Hees, W. W., \& Mead, B. R. (2000). Ocular estimates of understory vegetation structure in a closed Picea glauca/Betula papyrifera forest. Journal of Vegetation Science, 195-200.

van Laar, A., \& Akça, A. (2007). Forest Mensuration. New York: Springer. 385.pp 
Ward, J.S. (2015). Improving competitive status of oak regeneration using stand management and prescribed fires. Journal of Sustainable Forestry, 34:1-2, 105-124, DOI: $10.1080 / 10549811.2014 .973606$

Whitehead, D. R. \& Taylor, T. (2002). Acadian Flycatcher (Empidonax virescens), The Birds of North America Online (A. Poole, Ed.). Ithaca: Cornell Lab of Ornithology; Retrieved from the Birds of North America Online: http://bna.birds.cornell.edu/bna/species/614. doi:10.2173/bna.614

WV State GIS Data Clearinghouse. West Virginia GIS Technical Center. Web. 18 Feb. 2014.

Whitcomb, R. F., Robbins, C.S., Lynch, J.F., Klimkiewicz, B.L., \& Bystrak, D. (1981). Effects of forest fragmentation on avifauna of the eastern deciduous forest. Pages 125-206 in R. L. Burgess, and D. M. Sharpe, editors. Forest island dynamics in man-dominated landscapes. Springer-Verlag, New York.

United States Department of Agriculture. About the forest. Retrieved October 6, 2013, from http://www.fs.usda.gov/main/mnf/about-forest.

United States Department of Agriculture. Regional Sensitive Species List. Retrieved February 7, 2015, from http://www.fs.uda.gov/detail/r9/plants-animals/.

Yeiser, J. M., Baxley, D. L., Robinson, B. A., \& Morgan, J. J. (2015). Using prescribed fire and herbicide to manage rank native warm season grass for northern bobwhite. The Journal of Wildlife Management, 79(1), 69-76. 


\section{Table 1}

Mean $( \pm \mathrm{SE})$ vegetation characteristics measured at sampling sites in 2012 and 2013 in in burned (n=6 stands, 18 points in 2012,22 points in 2013), burned and managed $(n=3,6)$, and unburned stands $(n=6,22)$ in Monongahela National Forest, West Virginia, USA. Also shown are p-values for significance tests (ANOVA) for effects of severe storms (year effects), treatment type, and storm*treatment interactions; significant effects are shown with an $*(\alpha<0.05)$. Significant differences $(\alpha<0.05)$ are indicated with an *; superscripts indicate outcomes of multiple contrasts (LS Means Contrasts) in cases where vegetative parameters showed a response to management type $(\mathrm{p}<0.05)$. Year and year*treatment differences are shown graphically in Fig. 1.

\begin{tabular}{|c|c|c|c|c|c|c|}
\hline Variable & Burned & $\begin{array}{c}\text { Burn + } \\
\text { Managed }\end{array}$ & Unburned & Year & Treatment & $\begin{array}{c}\text { Year* } \\
\text { Treatment }\end{array}$ \\
\hline $\mathrm{n}$ seedlings & $1.5 \pm 0.3$ & $1.8 \pm 0.7$ & $1.3 \pm 0.2$ & $<0.01^{*}$ & 0.82 & 0.13 \\
\hline n saplings & $3.3 \pm 0.3^{\mathrm{A}}$ & $3.2 \pm 0.8^{\mathrm{B}}$ & $2.0 \pm 0.3^{\mathrm{C}}$ & 0.46 & $<0.01 *$ & 0.82 \\
\hline $\mathrm{n}$ trees & $4.1 \pm 0.4^{\mathrm{A}}$ & $6.2 \pm 0.7^{\mathrm{B}}$ & $8.4 \pm 0.3^{\mathrm{C}}$ & 0.29 & $<0.01^{*}$ & 0.39 \\
\hline understory height (m) & $1.7 \pm 0.2^{\mathrm{A}}$ & $1.3 \pm 0.3^{\mathrm{B}}$ & $2.4 \pm 0.2^{\mathrm{C}}$ & 0.21 & $<0.01 *$ & $<0.01 *$ \\
\hline litter depth $(\mathrm{cm})$ & $2.3 \pm 0.2^{\mathrm{A}}$ & $3.5 \pm 0.4^{\mathrm{B}}$ & $2.5 \pm 0.1^{\mathrm{A}}$ & $<0.01^{*}$ & $<0.01 *$ & 0.90 \\
\hline ground cover $(\%)$ & $0.3 \pm 0.0$ & $0.3 \pm 0.1$ & $0.4 \pm 0.0$ & 0.63 & 0.27 & 0.34 \\
\hline canopy cover $(\%)$ & $0.6 \pm 0.0^{\mathrm{A}}$ & $0.7 \pm 0.1^{\mathrm{B}}$ & $0.8 \pm 0.0^{\mathrm{B}}$ & $<0.01^{*}$ & $<0.01^{*}$ & 0.20 \\
\hline small shrub cover (\%) & $0.5 \pm 0.0^{\mathrm{A}}$ & $0.4 \pm 0.1^{\mathrm{B}}$ & $0.3 \pm 0.0^{\mathrm{C}}$ & $<0.01^{*}$ & $0.02 *$ & 0.90 \\
\hline medium shrub cover $(\%)$ & $0.4 \pm 0.0$ & $0.3 \pm 0.1$ & $0.4 \pm 0.0$ & $0.02 *$ & 0.43 & 0.17 \\
\hline tall shrub cover $(\%)$ & $0.3 \pm 0.0^{\mathrm{A}}$ & $0.2 \pm 0.1^{\mathrm{B}}$ & $0.4 \pm 0.0^{\mathrm{C}}$ & 0.06 & $<0.01 *$ & 0.12 \\
\hline
\end{tabular}




\section{Table 2}

Mean $( \pm \mathrm{SE})$ number of birds detected per point on point counts in 2012 and 2013 in burned ( $\mathrm{n}=6$ stands, 22 points in both years), burned and managed $(n=3,6)$, and unburned stands $(n=6,22)$ in Monongahela National Forest, West Virginia, USA. Bird species are categorized species of conservation concern (s) or aerial insectivores (i), or both; see text for details on categorization. Also shown are p-values for significance tests (ANOVA) for effects of severe storms (year effects), management type, and storm*management interactions. Significant differences $(\alpha<0.05)$ are indicated with an *; superscripts indicate outcomes of multiple contrasts (GLM Contrast) in cases where avian species showed a response to management type $(p<0.05)$. Year and year*treatment differences are shown graphically in Fig. 3.

\begin{tabular}{|c|c|c|c|c|c|c|}
\hline Bird Species & Burned & $\begin{array}{c}\text { Burn }+ \\
\text { Managed }\end{array}$ & Unburned & Year & Treatment & $\begin{array}{c}\text { Year * } \\
\text { Treatment }\end{array}$ \\
\hline Acadian Flycatcher (s, i) & $0.30 \pm 0.11^{\mathrm{A}}$ & $0.67 \pm 0.28^{\mathrm{B}}$ & $0.73 \pm 0.12^{\mathrm{B}}$ & $0.02 *$ & $0.02 *$ & 0.76 \\
\hline Black-billed cuckoo (s) & $0.00 \pm 0.00^{\mathrm{A}}$ & $0.33 \pm 0.26^{\mathrm{B}}$ & $0.00 \pm 0.00^{\mathrm{A}}$ & 1.00 & $>0.01^{*}$ & 1.00 \\
\hline Blue-headed vireo (i) & $0.23 \pm 0.06^{\mathrm{A}}$ & $0.17 \pm 0.11^{\mathrm{A}}$ & $0.50 \pm 0.08^{\mathrm{B}}$ & 1.00 & $0.04 *$ & $>0.01 *$ \\
\hline Cerulean warbler (s) & $0.00 \pm 0.00$ & $0.00 \pm 0.00$ & $0.14 \pm 0.05$ & 1.00 & 0.20 & 1.00 \\
\hline Eastern bluebird (i) & $0.07 \pm 0.04$ & $0.00 \pm 0.00$ & $0.00 \pm 0.00$ & 0.10 & 0.09 & 1.00 \\
\hline Eastern wood-pewee (i) & $0.98 \pm 0.25$ & $1.42 \pm 0.11$ & $0.84 \pm 0.14$ & $>0.01^{*}$ & 0.22 & 0.54 \\
\hline Great-crested flycatcher (i) & $0.02 \pm 0.15$ & $0.08 \pm 0.29$ & $0.05 \pm 0.21$ & 0.1 & 0.16 & 0.11 \\
\hline Hooded warbler (s) & $0.36 \pm 0.09$ & $1.50 \pm 0.29$ & $0.75 \pm 0.15$ & 0.1 & 0.37 & 0.11 \\
\hline Kentucky warbler (s) & $0.05 \pm 0.05$ & $0.00 \pm 0.00$ & $0.05 \pm 0.03$ & 0.1 & 0.44 & 0.42 \\
\hline Least flycatcher (i) & $0.43 \pm 0.15^{\mathrm{A}}$ & $0.33 \pm 0.33^{\mathrm{A}}$ & $0.00 \pm 0.00^{\mathrm{B}}$ & 0.1 & $>0.01 *$ & $0.02 *$ \\
\hline Louisiana waterthrush (s) & $0.11 \pm 0.05^{\mathrm{A}}$ & $0.42 \pm 0.15^{\mathrm{B}}$ & $0.16 \pm 0.06^{\mathrm{A}}$ & $>0.01 *$ & $0.04 *$ & $0.01 *$ \\
\hline Wood thrush (s) & $0.50 \pm 0.15$ & $1.17 \pm 0.13$ & $1.09 \pm 0.13$ & 0.09 & 0.12 & 0.62 \\
\hline Yellow-bellied sapsucker (s) & $0.00 \pm 0.00$ & $0.08 \pm 0.08$ & $0.00 \pm 0.00$ & 1.00 & 1.00 & 1.00 \\
\hline
\end{tabular}




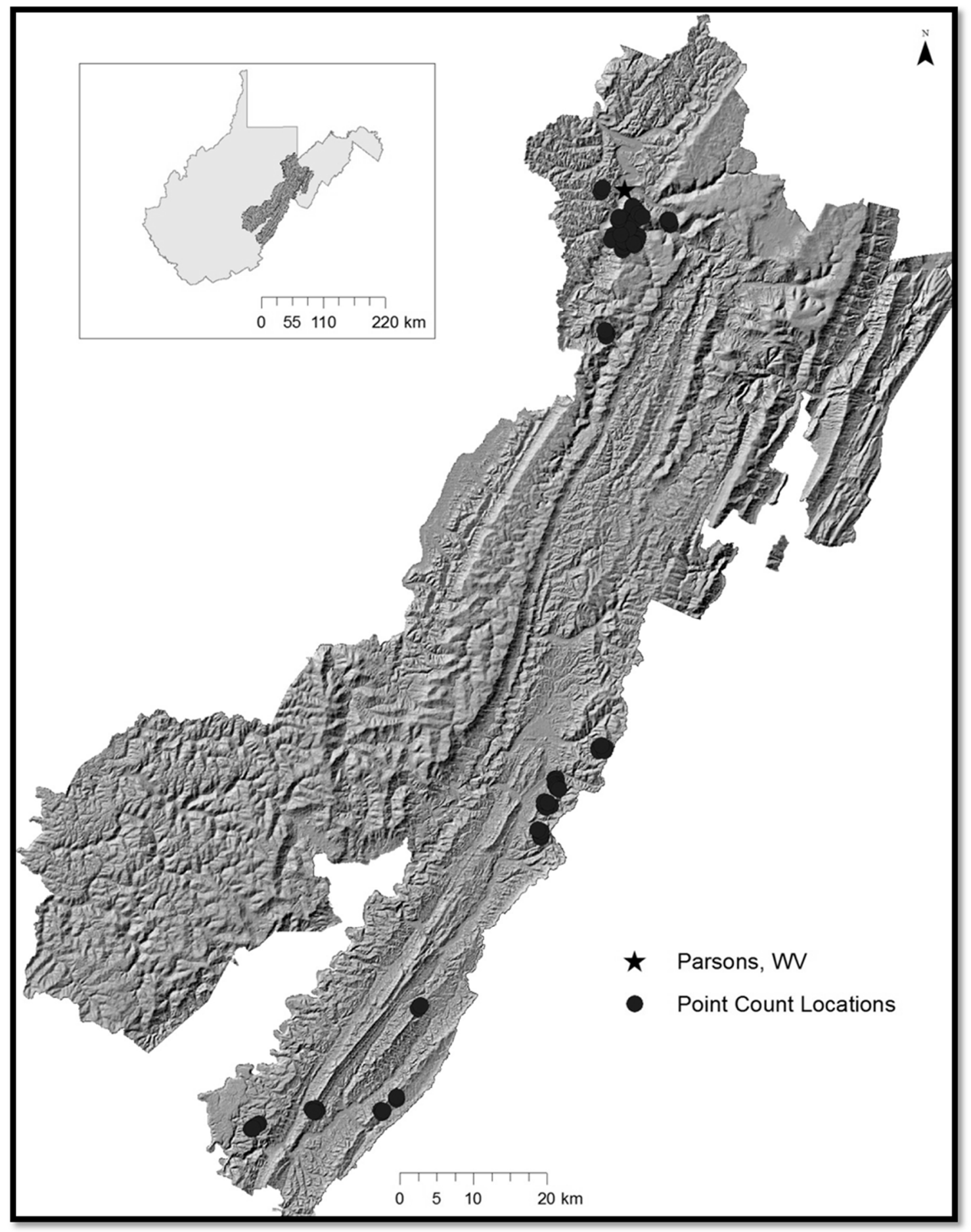

Figure 1. Greyscale topographic relief of the Monongahela National Forest (MNF) study area in eastern West Virginia. Avian and vegetative surveys were conducted at 50 points in 15 forest stands managed with prescription burning $(n=6)$, burning and other management $(n=3)$, and no burning $(n=6)$. The town of Parsons WV is shown with a star and the inset shows the location of the MNF within West Virginia. 

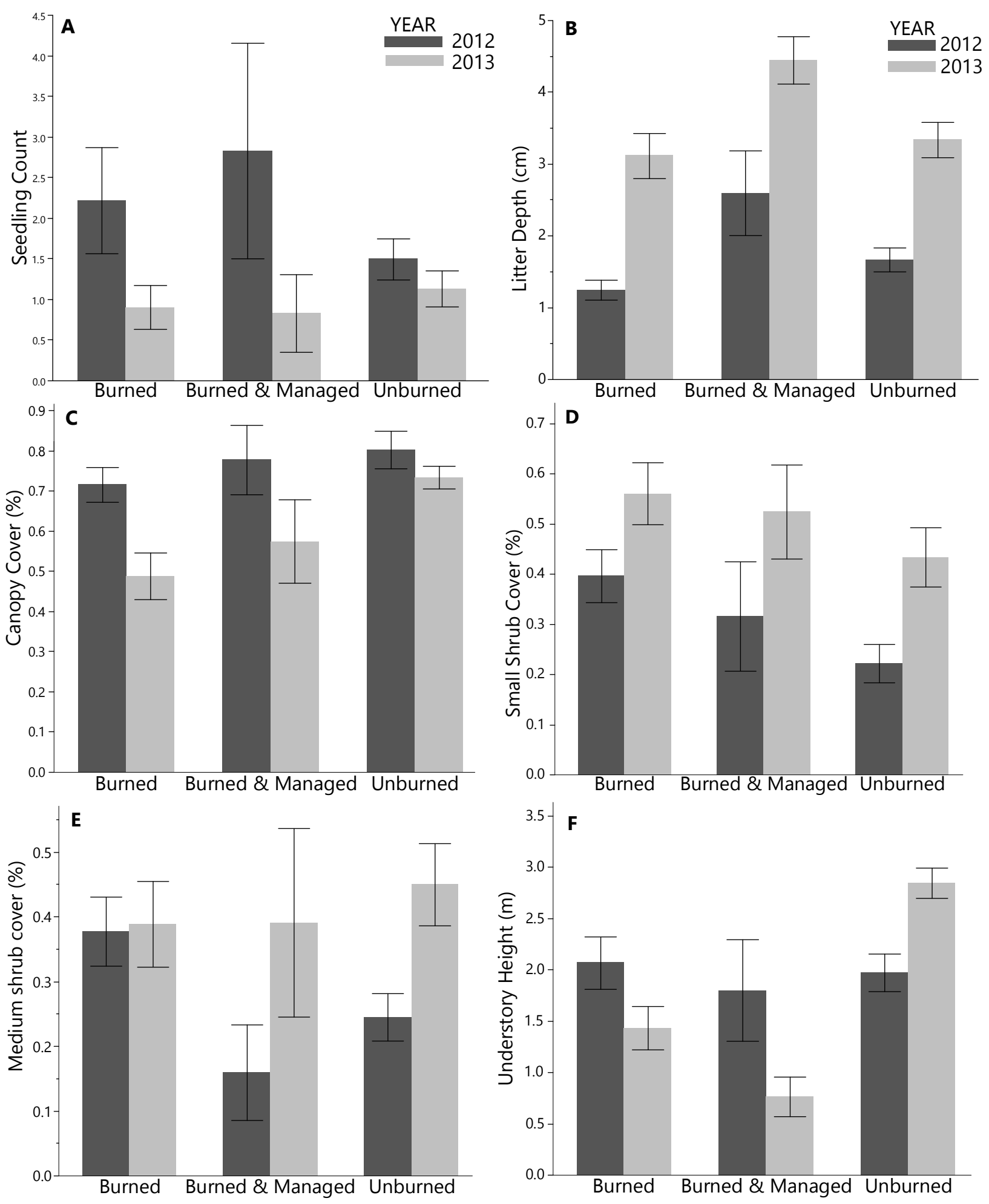
Figure 2. Vegetation parameters (mean $\pm \mathrm{SE}$ ) measured at 50 plots of 0.04 ha within the Monongahela National Forest in 2012 and 2013 in stands managed with prescribed burning $(\mathrm{n}=$ 6 stands, 22 points), burning and other management $(n=3,6)$, and with no burning $(n=6,22)$. Two severe storms impacted the landscape between sampling in 2012 and 2013. The six parameters shown are (A) count of seedlings per plot; (B) average litter depth; (C) percent canopy cover; (D) percent small shrub cover; (E) percent medium shrub cover; and (F) understory height. Note that $y$-axis scales are not identical among graphs. All six vegetation parameters presented here showed a response to either severe storms (a year effect) or a response to severe storms and management type (a year*treatment interaction). The first 5 vegetation parameters presented here showed a response to either severe storms (a year effect); understory height responded to severe storms and management type (a year*treatment interaction). See text for details on data collection techniques. 

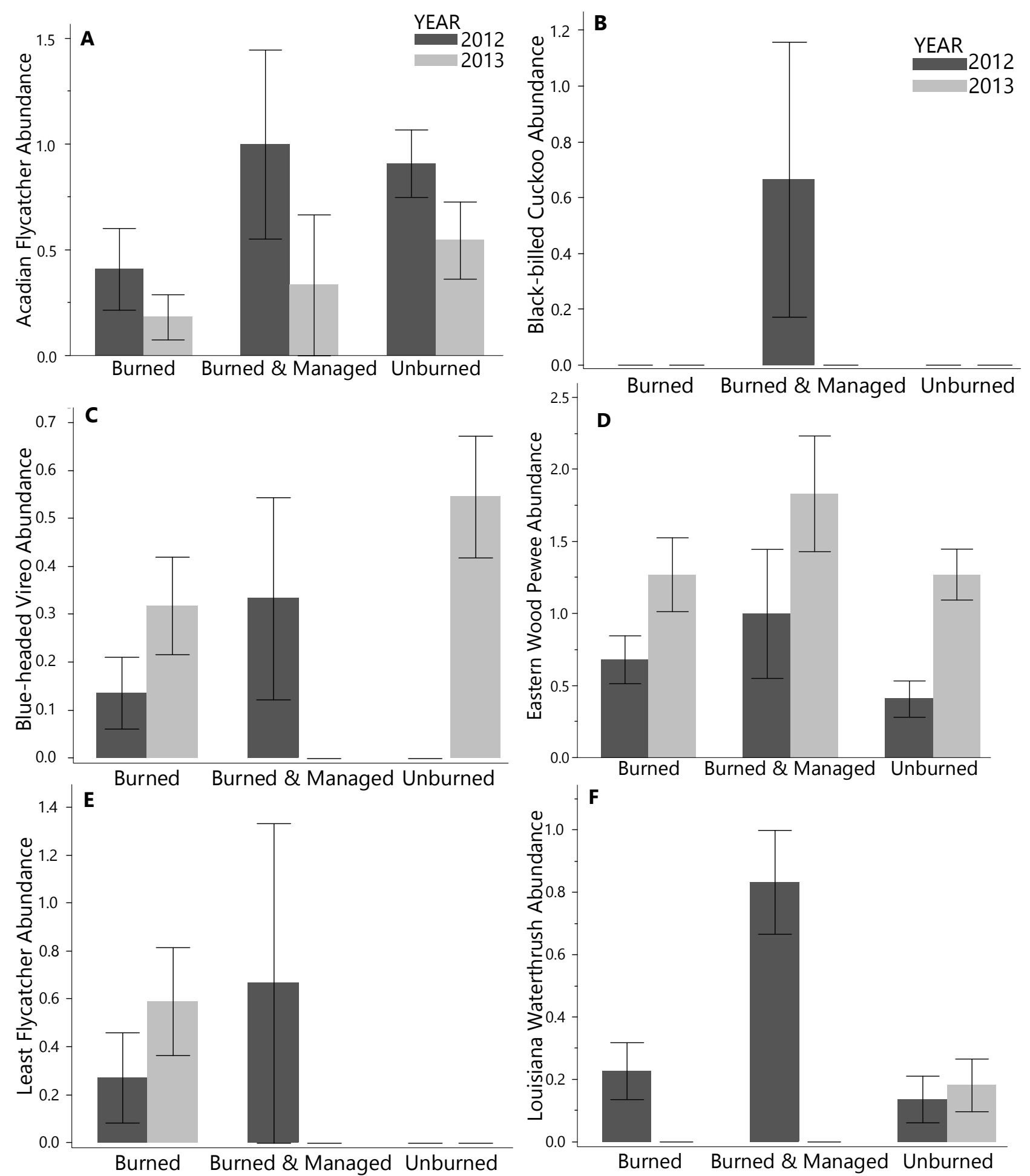
Figure 3. Abundance (mean $\pm \mathrm{SE}$ ) of focal bird species measured at 50 plots within the Monongahela National Forest in 2012 and 2013 in stands managed with prescribed burning $(\mathrm{n}=$ 6 stands, 22 points), burning and other management $(n=3,6)$, and with no burning $(n=6,22)$. Two severe storms impacted the landscape between sampling in 2012 and 2013. The six species shown are (A) Acadian flycatcher; (B) black-billed cuckoo; (C) blue-headed vireo; (D) eastern wood pewee; (E) least flycatcher; and (F) Louisiana waterthrush. The Acadian flycatcher, pewee and waterthrush all showed a response to severe storms (a year effect in our data). All species except the pewee showed a response to management type. Finally, the vireo, the least flycatcher and the waterthrush responded to interacting effects of storms and management. Note that y-axis scales are not identical. The error bars present represent SE. 
Appendix A. Stands sampled in the Monongahela National Forest of West Virginia for vegetation and birds in 2012 and 2013. Four stands were not sampled for vegetation in 2012 because they were inaccessible after post-storm blowdown.

\begin{tabular}{|c|c|c|c|c|c|c|c|c|c|c|c|c|c|c|c|c|}
\hline Stand & Point & Age Class & Year & Location & Management & Region & Elevation & \begin{tabular}{|l} 
Aspec \\
t
\end{tabular} & \begin{tabular}{|l} 
Slope \\
Position
\end{tabular} & Forest Type & \begin{tabular}{|l|} 
Seedling \\
2012
\end{tabular} & $\begin{array}{l}\text { Sapling } \\
2012\end{array}$ & $\begin{array}{l}\text { Tree } \\
2012\end{array}$ & \begin{tabular}{|l} 
Seedling \\
2013
\end{tabular} & \begin{tabular}{|l} 
Sapling \\
2013
\end{tabular} & $\begin{array}{l}\text { Tree } \\
2013\end{array}$ \\
\hline 1 & 3 & YOUNG & 2007 & FERNOW & $\begin{array}{l}\text { Burned and } \\
\text { Managed }\end{array}$ & $\mathrm{N}$ & 754 & 345 & Cove & Northern hardwoods & 7 & 3 & 10 & 1 & 1 & 6 \\
\hline 1 & 4 & YOUNG & 2007 & FERNOW & $\begin{array}{l}\text { Burned and } \\
\text { Managed }\end{array}$ & $\mathrm{N}$ & 643 & 127 & Steep_slope & Northern_hardwoods & 7 & 5 & 3 & 3 & 3 & 3 \\
\hline 1 & 5 & YOUNG & 2007 & FERNOW & $\begin{array}{l}\text { Burned and } \\
\text { Managed }\end{array}$ & $\mathrm{N}$ & 713 & 149 & Slope crest & Northern hardwoods & 1 & 6 & 10 & 0 & 10 & 6 \\
\hline 2 & 7 & YOUNG & 2007 & FERNOW & $\begin{array}{l}\text { Burned and } \\
\text { Managed }\end{array}$ & $\mathrm{N}$ & 756 & 322 & Cove & Mixed_mes_cove & 0 & 2 & 8 & 0 & 2 & 4 \\
\hline 3 & 12 & YOUNG & 2000 & FERNOW & $\begin{array}{l}\text { Burned and } \\
\text { Managed }\end{array}$ & $\mathrm{N}$ & 759 & 212 & Steep_slope & Mixed_mes_cove & 1 & 3 & 6 & 1 & 2 & 5 \\
\hline 3 & 13 & YOUNG & 2000 & FERNOW & $\begin{array}{l}\text { Burned and } \\
\text { Managed }\end{array}$ & $\mathrm{N}$ & 679 & 314 & Steep_slope & Mixed_mes_cove & 1 & 0 & 6 & 0 & 1 & 7 \\
\hline 14 & 26 & MID_AGE & 1960 & MON & Unburned & $\mathrm{N}$ & 731 & 245 & Steep_slope & Mixed_mes_cove & 2 & 0 & 10 & 2 & 0 & 10 \\
\hline 14 & 27 & MID_AGE & 1960 & MON & Unburned & $\mathrm{N}$ & 721 & 99 & Steep_slope & Mixed_mes_cove & 1 & 0 & 7 & 1 & 0 & 7 \\
\hline 14 & 28 & MID_AGE & 1960 & MON & Unburned & $\mathrm{N}$ & 737 & 91 & Steep_slope & Mixed_mes_cove & 1 & 2 & 8 & 1 & 2 & 9 \\
\hline 14 & 29 & MID_AGE & 1960 & MON & Unburned & $\mathrm{N}$ & 736 & 112 & Steep_slope & Mixed_mes_cove & 3 & 1 & 9 & 0 & 1 & 8 \\
\hline 15 & 34 & MATURE & 1922 & MON & Unburned & $\mathrm{N}$ & 986 & 289 & Steep_slope & Mixed_mes_cove & 1 & 2 & 8 & 0 & 4 & 9 \\
\hline 15 & 37 & MATURE & 1922 & MON & Unburned & $\mathrm{N}$ & 980 & 333 & Steep_slope & Mixed_mes_cove & 3 & 2 & 7 & 1 & 4 & 7 \\
\hline 15 & 38 & MATURE & 1922 & MON & Unburned & $\mathrm{N}$ & 987 & 309 & Steep_slope & Mixed_mes_cove & 2 & 2 & 10 & 1 & 0 & 12 \\
\hline 16 & 39 & MATURE & 1917 & MON & Unburned & $\mathrm{N}$ & 573 & 140 & Steep_slope & Mixed_mes_cove & 3 & 1 & 8 & 1 & 7 & 6 \\
\hline 16 & 40 & MATURE & 1917 & MON & Unburned & $\mathrm{N}$ & 614 & 122 & Steep_slope & Mixed_mes_cove & 1 & 5 & 8 & 0 & 4 & 8 \\
\hline 16 & 41 & MATURE & 1917 & MON & Unburned & $\mathrm{N}$ & 681 & 95 & Slope_crest & Mixed_mes_cove & 0 & 3 & 7 & 0 & 3 & 5 \\
\hline 16 & 42 & MATURE & 1917 & MON & Unburned & $\mathrm{N}$ & 728 & 72 & Steep_slope & Mixed_mes_cove & 2 & 2 & 10 & 0 & 2 & 8 \\
\hline 16 & 43 & MATURE & 1917 & MON & Unburned & $\mathrm{N}$ & 655 & 39 & Slope_crest & Mixed_mes_cove & 0 & 1 & 9 & 3 & 1 & 6 \\
\hline 17 & 45 & MATURE & 1914 & MON & Unburned & $\mathrm{N}$ & 863 & 81 & Slope_crest & Mixed_mes_cove & 1 & 2 & 8 & 2 & 2 & 6 \\
\hline 17 & 47 & MATURE & 1914 & MON & Unburned & $\mathrm{N}$ & 887 & 237 & Steep_slope & Mixed_mes_cove & 4 & 3 & 9 & 3 & 1 & 12 \\
\hline 17 & 48 & MATURE & 1914 & MON & Unburned & $\mathrm{N}$ & 906 & 297 & Steep_slope & Mixed_mes_cove & 3 & 1 & 9 & 0 & 1 & 13 \\
\hline 17 & 49 & MATURE & 1914 & MON & Unburned & $\mathrm{N}$ & 924 & 154 & Steep_slope & Mixed_mes_cove & 2 & 2 & 10 & 1 & 0 & 9 \\
\hline 18 & 50 & MATURE & 1920 & MON & Unburned & $\mathrm{N}$ & 887 & 147 & Cove & Mixed_mes_cove & 2 & 2 & 3 & 2 & 0 & 11 \\
\hline
\end{tabular}




\begin{tabular}{|c|c|c|c|c|c|c|c|c|c|c|c|c|c|c|c|c|}
\hline 18 & 51 & MATURE & 1920 & MON & Unburned & $\mathrm{N}$ & 950 & 186 & Steep_slope & Mixed_mes_cove & 1 & 1 & 5 & 1 & 2 & 6 \\
\hline 18 & 52 & MATURE & 1920 & MON & Unburned & $\mathrm{N}$ & 676 & 338 & Steep_slope & Mixed_mes_cove & 0 & 4 & 9 & 0 & 2 & 10 \\
\hline 18 & 53 & MATURE & 1920 & MON & Unburned & $\mathrm{N}$ & 715 & 218 & Steep_slope & Mixed_mes_cove & 1 & 1 & 9 & 1 & 3 & 7 \\
\hline 20 & 56 & MATURE & 1920 & MON & Unburned & $\mathrm{N}$ & 696 & 221 & Steep_slope & Mixed_mes_cove & 0 & 3 & 8 & 2 & 7 & 6 \\
\hline 20 & 57 & MATURE & 1920 & MON & Unburned & $\mathrm{N}$ & 802 & 305 & Cove & Mixed_mes_cove & 0 & 0 & 6 & 3 & 4 & 6 \\
\hline 4 & 70 & YOUNG & 2011 & MON & Burned & $\mathrm{S}$ & 1034 & 340 & Steep_slope & Oak & . & . & . & 0 & 1 & 0 \\
\hline 4 & 71 & YOUNG & 2011 & MON & Burned & $\mathrm{S}$ & 1069 & 328 & Cove & Oak & . & & . & 0 & 1 & 0 \\
\hline 4 & 72 & YOUNG & 2011 & MON & Burned & $\mathrm{S}$ & 1000 & 210 & Steep_slope & Oak & . & $\cdot$ & . & 0 & 6 & 5 \\
\hline 5 & 73 & YOUNG & 2011 & MON & Burned & $\mathrm{S}$ & 829 & 34 & Cove & Pine_Oak & 4 & 2 & 5 & 0 & 3 & 9 \\
\hline 5 & 74 & YOUNG & 2011 & MON & Burned & $\mathrm{S}$ & 829 & 107 & Slope_crest & Pine_Oak & 3 & 3 & 2 & 0 & 0 & 11 \\
\hline 5 & 75 & YOUNG & 2011 & MON & Burned & $\mathrm{S}$ & 817 & 331 & Steep_slope & Pine_Oak & 0 & 3 & 5 & 3 & 4 & 1 \\
\hline 5 & 76 & YOUNG & 2011 & MON & Burned & $\mathrm{S}$ & 833 & 94 & Steep_slope & Pine_Oak & 9 & 4 & 3 & 1 & 4 & 1 \\
\hline 5 & 77 & YOUNG & 2011 & MON & Burned & $\mathrm{S}$ & 873 & 56 & Steep_slope & Pine_Oak & 0 & 4 & 7 & 4 & 7 & 5 \\
\hline 6 & 78 & YOUNG & 2011 & MON & Burned & $\mathrm{S}$ & 879 & 223 & Slope_crest & Oak & 3 & 5 & 6 & 2 & 5 & 5 \\
\hline 6 & 79 & YOUNG & 2011 & MON & Burned & $\mathrm{S}$ & 901 & 303 & Slope_crest & Oak & 7 & 4 & 3 & 1 & 4 & 5 \\
\hline 7 & 80 & YOUNG & 2011 & MON & Burned & $\mathrm{S}$ & 917 & 141 & Steep_slope & Mixed_mes_cove & 2 & 6 & 5 & 1 & 5 & 7 \\
\hline 7 & 81 & YOUNG & 2011 & MON & Burned & $\mathrm{S}$ & 833 & 279 & Slope_crest & Mixed_mes_cove & 1 & 4 & 6 & 3 & 8 & 2 \\
\hline 7 & 82 & YOUNG & 2011 & MON & Burned & $\mathrm{S}$ & 909 & 220 & Slope_crest & Mixed_mes_cove & 5 & 6 & 2 & 3 & 5 & 4 \\
\hline 8 & 84 & YOUNG & 2012 & MON & Burned & $\mathrm{S}$ & 866 & 338 & Steep_slope & Oak & 1 & 2 & 5 & 0 & 2 & 6 \\
\hline 8 & 85 & YOUNG & 2012 & MON & Burned & $\mathrm{S}$ & 909 & 241 & Steep_slope & Oak & . & . & . & 0 & 3 & 6 \\
\hline 8 & 86 & YOUNG & 2012 & MON & Burned & $\mathrm{S}$ & 866 & 253 & Steep_slope & Oak & 0 & 3 & 5 & 0 & 7 & 4 \\
\hline 8 & 87 & YOUNG & 2012 & MON & Burned & $\mathrm{S}$ & 818 & 250 & Steep_slope & Oak & 0 & 3 & 6 & 1 & 5 & 8 \\
\hline 9 & 90 & YOUNG & 2010 & MON & Burned & $\mathrm{S}$ & 954 & 323 & Cove & Mixed_mes_cove_Oak & 0 & 2 & 7 & 0 & 1 & 9 \\
\hline 9 & 91 & YOUNG & 2010 & MON & Burned & $\mathrm{S}$ & 935 & 266 & Slope_crest & Mixed_mes_cove_Oak & 0 & 0 & 6 & 0 & 1 & 5 \\
\hline 9 & 92 & YOUNG & 2010 & MON & Burned & $\mathrm{S}$ & 928 & 236 & Steep_slope & Mixed_mes_cove_Oak & 5 & 2 & 7 & 1 & 1 & 3 \\
\hline 9 & 93 & YOUNG & 2010 & MON & Burned & $\mathrm{S}$ & 917 & 247 & Slope_crest & Mixed_mes_cove_Oak & 0 & 1 & 2 & 0 & 0 & 3 \\
\hline 9 & 94 & YOUNG & 2010 & MON & Burned & $\mathrm{S}$ & 933 & 241 & Steep_slope & Mixed_mes_cove_Oak & 0 & 2 & 3 & 0 & 2 & 4 \\
\hline
\end{tabular}


Appendix B. Total count of avian species detected over all three surveys at 50 points in the Monongahela National Forest in 2012 and 2013. Our study focused on 13 focal species (in bold), including AMJV high priority species $\left({ }^{a}\right)$ and aerial insectivores $\left({ }^{b}\right)$.

\begin{tabular}{|c|c|c|c|}
\hline Common Name & Scientific Name & Total \# in 2012 & Total \# in 2013 \\
\hline Acadian flycatcher ${ }^{\text {ab }}$ & Empidonax virescens & 35 & 22 \\
\hline American crow & Corvus brachyrhynchos & 27 & 28 \\
\hline American goldfinch & Spinus tristus & 14 & 21 \\
\hline American redstart & Setophaga rutcilla & 14 & 18 \\
\hline American robin & Turdus migratorius & 17 & 26 \\
\hline Baltimore oriole & Icturus galbula & 2 & 1 \\
\hline Barred owl & Strix varia & 0 & 1 \\
\hline Black-and-white warbler & Mniotilta varia & 20 & 53 \\
\hline Black-billed cuckoo $^{\text {a }}$ & Coccyzus erythropthalmus & 4 & $\mathbf{0}$ \\
\hline Bay-breasted warbler & Setophaga castanea & 0 & 15 \\
\hline Black-capped chickadee & Poecile atricpillus & 18 & 16 \\
\hline Blue-gray gnatcatcher & Polioptila caerulea & 0 & 1 \\
\hline Brown-headed cowbird & Molothrus ater & 2 & 2 \\
\hline Blue-headed vireo $^{b}$ & Vireo solitarius & 7 & 19 \\
\hline Blackburnian warbler & Setophaga fusca & 2 & 6 \\
\hline Blue jay & Cyanocitta cristata & 20 & 26 \\
\hline Brown creeper & Certhia americana & 1 & 1 \\
\hline Black-throated blue warbler & Setophaga caerulescens & 23 & 16 \\
\hline Black-throated green warbler & Setophaga virens & 46 & 51 \\
\hline Broad-winged hawk & Buteo platypterus & 1 & 4 \\
\hline Carolina wren & Thryothorus ludovicianus & 2 & 1 \\
\hline Cerulean warbler $^{\text {a }}$ & Setaphaga cerulea & 2 & 6 \\
\hline Chipping sparrow & Spizella passerina & 0 & 5 \\
\hline Common grackle & Quiscalus quiscula & 0 & 1 \\
\hline Chestnut-sided warbler & Setophaga pensylvanica & 10 & 48 \\
\hline Common yellowthroat & Geothlypis trichas & 2 & 22 \\
\hline Dark-eyed junco & Junco hymalis & 17 & 71 \\
\hline Downy woodpecker & Picoides pubescens & 10 & 1 \\
\hline Eastern bluebird $^{\text {b }}$ & Sialia sialis & 4 & $\mathbf{0}$ \\
\hline Eastern towhee & Pipilo erythrophthalmus & 55 & 71 \\
\hline Eastern turkey & Meleagris gallopavo & 1 & 4 \\
\hline Eastern wood-peewee $^{\text {b }}$ & Contopus virens & 47 & 69 \\
\hline Great-crested flycatcher ${ }^{b}$ & Myiarchus crinitus & 5 & 3 \\
\hline Gray catbird & Dumetella carolinensis & 2 & 7 \\
\hline Hairy woodpecker & Picoides villosus & 5 & 9 \\
\hline Hooded warbler ${ }^{\text {a }}$ & Setophaga citrina & 33 & 34 \\
\hline
\end{tabular}




\begin{tabular}{|c|c|c|c|}
\hline Indigo bunting & Passerina cyanea & 19 & 27 \\
\hline Kentucky warbler ${ }^{\text {a }}$ & Geothlypis formosa & 1 & 5 \\
\hline Least flycatcher ${ }^{b}$ & Empidonax minimus & 16 & 15 \\
\hline Lousiana waterthrush ${ }^{\text {a }}$ & Parkesia motacilla & 13 & 4 \\
\hline Magnolia warbler & Setophaga magnolia & 1 & 4 \\
\hline Mourning dove & Zenaida macroura & 15 & 12 \\
\hline Mourning warbler & Geothlypis philadelphia & 3 & 3 \\
\hline Northern cardinal & Cardinalis cardinalis & 2 & 3 \\
\hline Northern parula & Setophaga americana & 0 & 1 \\
\hline Ovenbird & Seiurus aurocapilla & 47 & 37 \\
\hline Pileated woodpecker & Dryocopus pileatus & 17 & 11 \\
\hline Raven & Corvus corax & 8 & 13 \\
\hline Rose-breasted grosbeak & Pheucticus ludovicianus & 14 & 20 \\
\hline Red-bellied woodpecker & Melanerpes carolinus & 12 & 5 \\
\hline Red-eyed vireo & Vireo olivaceus & 132 & 114 \\
\hline Red-headed woodpecker & Melanerpes erythrocephalus & 0 & 1 \\
\hline Red-tailed hawk & Buteo jamaicensis & 4 & 2 \\
\hline Ruby-throated hummingbird & Archilochus colubris & 0 & 2 \\
\hline Ruffed-grouse & Bonasa umbellus & 0 & 5 \\
\hline Red-winged blackbird & Agelaius phoeniceus & 0 & 6 \\
\hline Scarlet tanager & Piranga olivacea & 61 & 61 \\
\hline Tufted titmouse & Baeolophus bicolor & 19 & 23 \\
\hline Turkey vulture & Cathartes aura & 2 & 1 \\
\hline Veery & Catharus fuscescens & 18 & 33 \\
\hline White-breasted nuthatch & Sitta carolinensis & 43 & 11 \\
\hline Winter wren & Troglodytes hiemalis & 5 & 3 \\
\hline Wood thrush ${ }^{\text {a }}$ & Hylocichla mustelina & 53 & 35 \\
\hline Yellow-bellied sapsucker ${ }^{\text {a }}$ & Sphyrapicus varius & $\mathbf{0}$ & 3 \\
\hline Yellow warbler & Setophaga petechia & 1 & 7 \\
\hline Yellow-rumped warbler & Setophaga coronata & 0 & 4 \\
\hline Yellow-shafted flicker & Colaptes auratus & 6 & 2 \\
\hline Yellow-throated vireo & Vireo flavifrons & 5 & 0 \\
\hline
\end{tabular}




\section{Chapter 2}

\section{WHIP-POOR-WILLS ARE NEGATIVELY ASSOCIATED WITH HIGH ELEVATION AND HIGHLY FRAGMENTED LANDSCAPE IN RURAL WEST VIRGINIA}

Formatted in the style of Wilson Journal of Ornithology 


\begin{abstract}
Populations of the eastern whip-poor-will (Antrostomus vociferus) are declining due to a range of potential factors including habitat loss, pesticide use and predation. However, because this species is nocturnal, it is poorly studied and neither its ecology nor its demographic status are well measured by traditional bird surveys like the Christmas Bird Count, Breeding Bird Surveys, and point-count surveys. Therefore, we studied habitat associations and distribution of eastern whip-poor-wills to better understand and contextualize their population status and to provide a framework for research and management. Transect data were analyzed with occupancy models to associate presence of whip-poor-wills with habitat characteristics. We observed habitat associations of and annual differences in both presence and number of whip-poor-wills. Whippoor-wills most frequently occupied areas lower in elevation and mixed forest, herbaceous, as well as wetland cover types. In contrast, high elevation evergreen forest communities had substantially fewer whip-poor-wills. Our results suggest that succession of agricultural fields and other clearings to forested habitats with dense understory may be contributing factor to whippoor-will declines.
\end{abstract}


Populations of avian aerial insectivores are declining (Sauer et al. 2011) more rapidly than those of many other birds of great conservation concern (Nebel et al. 2010). Putative causes for these declines are linked to predation, pesticide use for Lepidopterans, climate change, and loss of habitat (Cink 2002, Nebel et al. 2010, Dunn et al. 2011, Hunt 2013). The declines of aerial insectivores are of concern because variation in their number may indicate underlying ecosystem changes (Nebel et al. 2010).

The aerial insectivore guild includes the family Caprimulgidae. Members of this family are characterized by cryptic coloration, wide mouths, large eyes and the ability to take insects on the wing (Cink 2002). North American species in this family include the common nighthawk (Chordeiles minor), lesser nighthawk (Chordeiles acutipennis), chuck-will's-widow (Caprimulgus carolinensis), common poorwill (Phalaenoptilus nuttallii), Mexican whip-poorwill (Antrostomus arizonae) and eastern whip-poor-will (Antrostomus vociferus). All of these species are nocturnal, making them difficult to survey, and thus BBS data for Caprimulgids often either show either no trend or large errors around trend estimates. Nevertheless, there is documentation from limited BBS data that populations of the first three species are experiencing significant declines (Sauer et al. 2011). However, the remaining two species, the common poorwill and eastern whip-poor-will show no survey-wide trend or the data provide imprecise population estimates (Sauer et al. 2011). As such, there is an important need to understand how these populations are faring and to identify steps that may be relevant to their conservation and management using more appropriate survey techniques.

To address this need, we focused research on the nesting and foraging habitat associations and distribution of eastern whip-poor-will in the central Appalachians. Historic accounts mention eastern whip-poor-will nesting habitat as dry, well-drained ground at the edge 
of mixed oak (Quercus spp.), beech (Fagus spp.), and pine forest (Pinus spp.) with little to no underbrush and uncrowded trees (Bent 1989). In some accounts, the openness of forest understory is more important in determining appropriate nesting habitat than the composition of the forest (Wilson 1985). More recent literature also lists eastern whip-poor-wills as preferring areas with dry soils in pine, beech or oak forests for nesting (Cink 2002). The historic accounts of foraging habitat indicate the species feeds on the wing in open fields and forest clearings (Bent 1989). Current accounts of eastern whip-poor-will foraging habitat preferences also suggest that they use open areas like power line right-of-ways, regenerating clear-cuts, recent burns, and wetlands (Wilson 2003, Hunt 2006). In New Hampshire, the species is reported to be positively correlated with presence of pine forests and large areas of clearcut forest and negatively associated with high elevation dense forest cover, and high amounts of human development (Hunt 2006). In West Virginia, historic accounts list eastern whip-poor-wills as being present in oak-hickory (Carya spp.), white pine (Pinus alba), or hardwood-hemlock (Tsuga canadensis) forest and sparingly in northern hardwoods (Hall 1983).

There are no data available on the minimum size of forest plots needed to sustain a breeding pair of eastern whip-poor-wills (Cink 2002). Previous telemetry-based studies in New Hampshire found the average home range size of eastern whip-poor-wills to be about 5 ha in shrubland habitat but up to 13 ha in heavily forested areas (Hunt 2013). In north central Maryland, small isolated woodlots amongst an agricultural matrix provided poor whip-poor-will habitat and were generally not occupied by whip-poor-wills (Reese 1996). Therefore, the size of forest stands and proximity of those forest stands to larger forest stands may be important in determining whether an area is suitable habitat for whip-poor-wills (Cink 2002). 
We studied occupancy and distribution of eastern whip-poor-wills to better understand their habitat associations and to gain insight into how their populations may be responding to modern land use practices. In particular, we sought to answer the following questions A) what nesting and foraging land cover types are associated with eastern whip-poor-will presence?; and, B) what is the expected distribution of the species within the Monongahela National Forest (MNF) in the central Appalachian Mountains? Finally we discuss these patterns in the context of potential habitat alteration and climate change within this region.

\section{METHODS}

Study Area

We collected data on eastern whip-poor-wills within the MNF and surrounding lands of West Virginia, USA (Fig. 1). The MNF stretches over 305,538 ha within the Central Allegheny Mountain province of the Appalachian Plateau in West Virginia (Ferguson and Marquis 1964). Elevation within the MNF ranges 305-1,482 meters above sea level (United States Department of Agriculture 2013). The western side of the MNF receives about 152 centimeters of rain per year while the eastern side receives about 76 centimeters per year (United States Department of Agriculture 2013). Portions of our survey locations bordered land not managed by the United States Forest Service. These properties often included houses, pasture, and forest.

\section{Focal species}

The eastern whip-poor-will is a ground-nesting bird distributed across most of eastern North America. The species is predated by a range of reptilian, avian and mammalian predators (Santner 1992, Cink 2002) and is also thought to be impacted by a variety of anthropogenic 
forces. Male eastern whip-poor-wills establish territories that include nesting and foraging habitat once they have reached the breeding grounds (Cink 2002). Once the territory is established the males will sing from nesting and foraging portions of the territory. Intensity of singing is the greatest during breeding season but will occur throughout the year (Mills 1986, Cink 2002). Singing intensity is also greatest at dusk and dawn and on moonlit nights (Stoner 1920, Mills 1986). Both male and female whip-poor-wills have a brood patch and take part in incubation of eggs as well as brooding of young (Raynor 1941, Babcock 1975, Cink 2002). Parents will frequently exchange places to forage, beginning at dusk (Cink 2002).

\section{Sampling Strategy}

We surveyed for whip-poor-wills along roads throughout the MNF and surrounding areas. Using ArcMap 10.1, roads were selected that ran through or were close to habitat thought to be preferred by the species, including burned forest stands, conifers, and agricultural lands (Cink 2002). Roads also had to be at least $16 \mathrm{~km}$ in length so that we would be able to place 10 point locations along the road that would be $1.6 \mathrm{~km}$ apart. From over 70 roads that ran through appropriate habitat, we randomly chose 10 that were close enough to each other and to our field camp to allow for ease of access. Five of the roads were located in the northern portion of the forest and the other 5 were in the southern portion of the forest (Fig. 1).

We conducted surveys using protocols from The Center for Conservation Biology’s (CCB) United States Nightjar Survey (Center for Conservation Biology 2012). CCB protocols suggest that the best time periods for surveys during our summer field seasons were May 28June 11 and June 27-July 11. These periods corresponded with the brightest moonlight in the season; detection rates of whip-poor-wills are thought to be highest in bright moonlight (Wilson 
and Watts 2006). Roads were surveyed twice each during 2012 and 2013. Surveys began half an hour after sunset and ended 15 minutes before sunrise. We varied survey start times among transects to account for site-specific differences in vocalizing. Surveys were not conducted if it was rainy, if winds exceeded $24 \mathrm{kph}$, or if dense cloud cover obscured the sky.

On each transect, we stopped ten times, once every $1.6 \mathrm{~km}$, to survey for whip-poor-wills (two roads were only long enough for 8-9 points; total number of points surveyed was $n=95$ ). There were two observers present throughout the surveys and they would share information on birds heard. Each point location was surveyed for six minutes and we recorded individual birds that were heard. At each point, data were also collected on cloud cover (\%), wind (0-3), noise levels (0-2), and moon visibility (0-1). Two or three road surveys were generally completed each night.

\section{Data associations}

There have been suggestions that observations of individual whip-poor-wills are independent at 1600m apart (Hunt 2003) and the CCB survey protocol used to collect data assumes that transect stops are independent at $1600 \mathrm{~m}$ apart.

We created a buffer of $1600 \mathrm{~m}$ around each transect stop location, and then used zonal statistics to tabulate areas $\left(\mathrm{m}^{2}\right)$ of the following land cover types: developed, deciduous forest, evergreen forest, mixed forest, herbaceous/ hay/pasture/shrub, cultivated crops, and wetland (USGS 2006 NLCD Land Cover Classifications; Appendix A; Fry et al. 2011). Within the buffer, we also calculated the total length of forest edge. Although newer data exist today, the NLCD 2006 land cover data were the most current available when survey locations were selected. In addition, we calculated elevation at each point using a 2003 USGS digital elevation 
model (West Virginia GIS Technical Center 2013). All spatial data collection and interpretation was conducted within ArcMap10.1 (ESRI 2013). Spatial and habitat data associated with each point are provided in the appendix (Appendix B). Elevation across the buffer was calculated as an average in ArcMap 10.1.

\section{Statistical Analysis - Occupancy Modeling}

To determine patterns of occupancy by whip-poor-wills, we used single-species multiple season occupancy modeling in program PRESENCE (MacKenzie et al. 2012). The assumptions of this model include independence of survey stops within years, no colonization or extinction within years, the potential for heterogeneity between survey stops across years, and no false detections of eastern whip-poor-wills (MacKenzie et al. 2006). Model parameters included the occupancy rate by year (i.e. probability of eastern whip-poor-will being present; $\Psi$ ), the rate of occupancy change, designated as $\Lambda_{t}$ and estimated as $\Psi_{t+1} / \Psi_{t}$, the between-year extinction probability at survey stops $\left(\varepsilon_{t}=P(\right.$ absence at time $t+1 \mid$ presence at $\left.t)\right)$, colonization probability at survey stops $\left(\gamma_{t}=P(\right.$ presence at time $t+1 \mid$ absence at $\left.t)\right)$, and detection probability (i.e. the probability of hearing an eastern whip-poor-will, $p$ ) (MacKenzie et al. 2006).

PRESENCE uses maximum likelihood techniques to estimate both the parameters noted above and resight probabilities. We converted survey data into detection histories using the presence (1) and absence (0) data collected during surveys (MacKenzie et al. 2012). If even one eastern whip-poor-will was detected at an individual transect location a "1" for presence was listed for the minutes a whip-poor-will was detected. Information for both surveys in a year was combined to ensure that information was being averaged over a season and that we were accurately able to determine whether a whip-poor-will was ever present at a location during our 
sampling period. We used logistic regression with a logit link to model the probability that a survey stop would be occupied by eastern whip-poor-wills as a function of the elevation, edge and the land cover covariates. Year, moon visibility and noise level (0-2) were similarly used as covariates to calculate only detection probabilities. Using logistic regression allows covariate values to be scaled to a probability between 0 and 1 . The untransformed beta values given in the PRESENCE output are calculated using logistic regression and were used to calculate an odds ratio (i.e. the odds of a whip-poor-will being present in comparison to being absent) and then transformed to model percent of occupancy at the survey stops. The equation for calculating the odds ratios is $\widehat{O R}_{\text {covariate }}=e^{\widehat{a 1}}$ where a1 $=$ an untransformed beta estimate. The equation for calculating percent occupancy, given our edge, elevation, or land cover type covariates, is $\widehat{\Psi}_{\text {covariate }}=e^{\widehat{a 1}} / 1+e^{\widehat{a 1}}$ where $\Psi=$ percent occupancy, a1 $=$ an untransformed beta estimate (MacKenzie et al. 2006). The "hats" in these last two equations designate estimated values. To rank models in the model set, we used quasi-Akaike's information criterion values (QAIC), which represents model fit with the minimum number of parameters and is estimated in PRESENCE. $\mathrm{AIC}_{\mathrm{C}}$ weights are used in model averaging and provide a measure of the strength of evidence for each model. $\mathrm{AIC}_{\mathrm{C}}$ weights are also given in the PRESENCE output (Burnham and Anderson 2002). Log likelihoods in the PRESENCE output showed the absolute fit of the models to the data (MacKenzie et al. 2012).

Statistical Analysis - Modeling Whip-poor-will Occupancy

To model the influence of sampling and site covariates on occupancy and detection, we developed a priori models based on previous literature and evaluated the models using an AIC approach (Burnham and Anderson 2002). We used 6 sub-models to determine effects of site 
covariates (elevation, forest edge, area open water, area cultivated crops, area

herbaceous/shrub/pasture land, area deciduous forest, area evergreen forest, area mixed forest, area developed, and area wetland) on occupancy and sampling covariates (moon visibility, noise, and year) on detection (Table 1, 2). In each model, colonization and emigration were held constant and equal but are still counted as two of the model parameters. The rest of the parameters come from the site and sampling covariates used to estimate occupancy and detection probabilities. Site and sampling covariates were converted to Z-scores to reduce the influence of variables that had larger ranges (Donovan and Hines 2007). Program PRESENCE (MacKenzie et al. 2006) was used to estimate occupancy ( $\Psi)$, detection $(p)$, colonization $(\gamma)$, and extinction $(\varepsilon)$, as well as to compute the $\beta$ values for site and sampling covariates included in the models (MacKenzie et al. 2006)(Table 2).

We used model averaging to account for model selection uncertainty among each of the models with any support in the model set. After model averaging, we calculated odds ratios and percent occupancy using untransformed beta values provided by PRESENCE.

To predict the distribution of the eastern whip-poor-will within the MNF, we used the raster calculator tool (ESRI 2013) to apply the averaged model built above to USGS NLCD 2006 raster data for the entire MNF. The output layer included a map of areas with probabilities of whip-poor-will occupancy based on land cover type.

\section{RESULTS}

We recorded 181 vocalizing eastern whip-poor-wills in 2012 (1.9/point) and 101 in 2013 (1.0/point). Deciduous forest was the most common land cover type surrounding the survey roads comprising $78 \%$ of all the land cover within $1600 \mathrm{~m}$ circles, while wetlands was the least 
common land cover type comprising less than $1 \%$ of the total cover at that same scale. The road and points considered to have the most development surrounding it was the Fernow Road (USFS road 301) with a total developed area of $3,116 \mathrm{~km}^{2}$ (Appendix B).

Because of the short time window for sampling, weather sometimes constrained our ability to complete all planned surveys. In 2012, five transects were impacted by weather. One was only sampled once and four were sampled once fully and once partially. In 2013 two transects were only sampled once and 5 transects were partially completed. Missing data were accounted for in program PRESENCE (MacKenzie et al. 2006).

\section{Elevation, Forest Edge and Landscape Associations}

We compared models based on $1600 \mathrm{~m}$ buffers to understand eastern whip-poor-will land cover selection. The first two models, which together had $78 \%$ of the support in the data, suggest that elevation is more influential in determining whip-poor-will occupancy than land cover covariates (Table 1). Edge was also listed in the models but the SE value is higher than the parameter estimate making this covariate not biologically meaningful. The models of eastern whip-poor-will occupancy that included land cover classes only accounted for $22 \%$ of the support in the data (Table 1). The most highly supported model had 1.5 times more support than the next best model and 3 times more support than the $3^{\text {rd }}$ ranked model (the first which included land cover class; Table 2). Because there was some support for the model that included land cover covariates in addition to elevation, we were able to model average to determine occupancy based on land cover covariates. Model averaged results suggested (a) negative associations of whip-poor-will occupancy with elevation and (b) increasing areas of mixed forest and herbaceous/shrub/pasture cover were positively associated with whip-poor-will occupancy, while 
increasing areas of open water, evergreen forest, development, cultivated crop land, and wetlands were negatively associated with whip-poor-will occupancy (Table 3). Eastern whip-poor-wills were twice as likely to be found in mixed forest or herbaceous/shrub/pasture areas than they were in other land cover types (Table 3). Although deciduous forest was associated with the highest probability of whip-poor-will occupancy, area of deciduous forest did not fit our models well (the SE of this parameter is higher than the parameter estimate).

\section{Distribution of Whip-poor-will within the Monongahela National Forest}

We then applied the previous analyses to model occupancy rates throughout the MNF using elevation, and land cover occupancy estimates as well as elevation and land cover raster data. The model predicts multiple locations throughout the MNF that would be suitable for eastern whip-poor-will occupancy (Figure 2). Our models suggest that areas of lower elevation, mixed forest and shrub and grassland were more highly weighted than other areas. It appears that there are many locations, of low enough elevation, spread across the MNF where eastern whippoor-wills may be found during the breeding season.

\section{DISCUSSION}

\section{Scale of Land Cover Use}

A significant proportion of the MNF is covered by closed canopy deciduous forest and the lowest elevation is around 305m (United States Department of Agriculture 2013). Because the birds we found were at lower elevations, it may be that high elevation mountainous areas in the MNF are not suitable breeding and foraging habitat for this species. This finding is supported 
by literature that found whip-poor-wills were absent above 305m in the Adirondack and Catskill mountains (Sibley 1988).

Previous telemetry-based studies in New Hampshire found whip-poor-wills were much more likely to be detected at elevations below 180m (Hunt 2006). In our study area however, the lowest elevation of our survey points was 305m. During our study eastern whip-poor-wills were never detected in areas along the Dolly Sods road which were higher than $900 \mathrm{~m}$. These patterns suggest that this species has specific habitat preferences related to elevation and that occupancy across landscapes may therefore show dramatic variation in mountainous habitat such as the MNF.

\section{Land Cover Types}

Previous literature suggests that eastern whip-poor-wills require a mosaic of young forest and open areas for nesting and foraging (Wilson and Watts 2008, Hunt 2013). We found that deciduous forest, mixed forest and shrub and grassland were the land cover types most likely to be occupied by eastern whip-poor-wills. These relationships could be driven by prey and foraging availability, thermal constraints, or even mating and breeding opportunities. Likewise, whip-poor-wills were negatively associated with open water, development, evergreen forest, cultivated crops, and wetlands. The negative association with evergreen forest is inconsistent with the findings of previous studies. However, the little conifer forest that occurs on the MNF is found only at high elevations and elevation plus differences in tree species and climate may thus drive this relationship.

Previous literature suggests that eastern whip-poor-wills prefer clear-cut forest areas (Hunt 2013). The land cover dataset we used did not allow us to differentiate between managed 
and unmanaged forest types and we did not feel that we would be able to accurately measure size and boundaries of managed vs. unmanaged areas from the road. Nevertheless, this analysis points to clear patterns in use and avoidance of specific habitat types that are useful in predicting distributions and in developing potential conservation measures for this and related species. Future studies could incorporate known managed forest plot areas to determine to what extent they influence whip-poor-will occupancy.

\section{Predicting Occupancy in the MNF}

One of the goals of this study was to use a survey protocol designed specifically for nightjars to create a map of eastern whip-poor-will occupancy in the MNF. To our knowledge this approach has never before been attempted with CCB United States Nightjar Survey protocols for nighttime surveys. Our approach - evaluating survey data with occupancy models - produced a map that can now be field validated and that provides detailed predictions on where eastern whip-poor-wills may be found in the MNF.

The creation of our occupancy map is also useful because it allows us to identify areas in the MNF that are potentially well suited to new nightjar survey routes. Increasing the number of survey routes will allow MNF scientists and forest managers to have a more reliable estimate of eastern whip-poor-will population numbers in West Virginia. Our models suggest that multiple portions of the MNF might be well suited to detect this species.

We believe our model of whip-poor-will occupancy is a useful guide for similar work in other National Forests. While other National Forests have different land cover compositions than the MNF, we have provided evidence that an occupancy modeling approach is useful for understanding potential distribution of this species across a landscape. Knowing the land cover 
types that were positively correlated with whip-poor-will occupancy in this study could give managers in other forests a place to start when establishing eastern whip-poor-will survey routes and eventual locally specific predictive mapping exercises.

\section{Whip-poor-will distribution over time}

Whip-poor-wills were present in every West Virginia County during the 1920's, a period that followed heavy settlement and logging (Hall 1983). However, whip-poor-will numbers are thought to have steadily decreased since the 1950 s, as widespread succession occurrs, replacing agricultural fields and intensely logged areas with dense forest (Hall 1983, Buckelew and Hall 1994). They have also disappeared from many parts of the country including much of southeast Pennsylvania (Santner 1992). Much of the change is a result of loss of habitat to urbanization, agricultural crops and grazing (Cink 2002). Management of forests through clear-cutting, overstory removal, and prescribed burning have been suggested to provide additional whip-poor-will habitat (Hunt 2013.)

Future habitat changes may also have impacts on eastern whip-poor-will populations. As the climate changes, the severity of storms the MNF experiences is likely to increase (Simmonds and Keay 2009, Tang et al. 2013). These severe storms cause widespread damage to forests, including felling of over-story trees, all of which may create forest more suitable for whip-poorwills. Alternatively, as the climate is warming, the first flight periods of insects is occurring earlier in the year, a process which could lead to mismatches of whip-poor-will reproduction with peak food abundance (Dingemanse et al. 2008, Møller et al 2008, Polgar et al. 2013). Because spring migration is usually photoperiod-dependent and insect outbreaks are temperature-dependent (Both and Visser 2001), and because reproductive success of aerial 
insectivores is highly dependent on food abundance (Dunn et al. 2011), this aspect of climate change may negatively impact whip-poor-wills. Pesticide use targeted at gypsy moths and occurring from $\sim 1950$ - present could further compound the food abundance problem (Cink 2002, Hunt 2014). Thus, the monitoring tool our study provides should be a useful mechanism to track the occupancy of this species and its potential response to future habitat changes. 


\section{LITERATURE CITED}

Akaike, H. 1973. Information theory as an extension of the maximum likelihood principle. Pages 267-281 in Second international symposium on information theory (B.N. Petrov, and F. Csaki , Editors). Budapest, Akaemiai Kiado.

Babcock, R.E. 1975. Another instance of incubation by a male Whip-poor-will. Wilson Bulletin 87:284.

Bent, A.C. 1989. Dover Publications. Pages 163-183 in Life histories of North American cuckoos, goatsuckers, hummingbirds, and their allies. Volume1.

Both, C., and M.E. Visser. 2001. Adjustment to climate change is constrained by arrival date in a long-distance migrant bird. Nature 411: 296-298.

Buckelew, A. R. and G.A. Hall. 1994. The West Virginia breeding bird atlas. Pitt Series in Nature and Natural History. USA.

Burnham, K. P. and D.R. Anderson. 2002. Model selection and multimodel inference: A practical information-theoretic approach. Springer Science \& Business Media.

Center for Conservation Biology. 2012. Survey Instructions. Nightjar Survey Network. Williamsburg, Virginia, USA. http:/www.nightjars.org/participate/survey-instructions/ (accessed 3 January 2012).

Cink, C. L. 2002. Avian predation on the eggs of the Whip-poor-will. Bull. Kansas Ornithological Society 53:23-24.

Cink, C. L. 2002. Eastern Whip-poor-will (Antrostomus vociferus), The birds of North America. Number 620.

Dingemanse, N. J. and V.J. Kalkman. 2008. Changing temperature regimes have advanced the phenology of odonata in the Netherlands. Ecological Entomology 33:394-402. 
Donovan, T. M. and J. Hines. 2007. Exercises in occupancy modeling and estimation. http://www.uvm.edu/envnr/vtcfwru/spreadsheets/occupancy.htm (accessed 3 May 2014).

Dunn, E. H. 2002. Using decline in bird populations to identify needs for conservation action. Conservation Biology 16:1632-1637.

Dunn, P. O., Winkler, D. W., Møller, A., Fiedler, W. and P. Berthold. 2010. Effects of climate change on timing of breeding and reproductive success in birds. Effects of Climate Change on Birds. 113-128.

Dunn, P. O., Winkler, D. W., Whittingham, L. A., Hannon, S. J. and R.J. Robertson. 2011. A test of the mismatch hypothesis: How is timing of reproduction related to food abundance in an aerial insectivore? Ecology 92: 450-461.

ESRI (Environmental Systems Resource Institute). 2013. ArcMap 10.1. ESRI, Redlands, California.

Ferguson, R.H. and R.W. Marquis. 1964. The Timber Resources of West Virginia. United States Forest Service Resource Bulletin NE-2. Northeastern Forest Experiment Station. Upper Darby, Pennsylvania, USA.

Fry, J., Xian, G., Jin, S., Dewitz, J., Homer, C., Yang, L., Barnes, C., Herold, N. and J. Wickham. 2011. Completion of the 2006 National Land Cover Database for the Conterminous United States, PE\&RS, Vol. 77:858-864.

Hall, G. A. 1983. West Virginia birds: distribution and ecology. Carnegie Museum of Natural History.

Hunt, P. D. 2006. An Analysis of Whip-poor-will Habitat Use in the Piscataquog River Watershed: 2003-2005. Report to the Piscataquog Watershed Association. Audubon Society of New Hampshire, Concord. 
Hunt, P. D. 2013. Habitat Use by the Eastern Whip-poor-will (Antrostomus vociferus) in New Hampshire: with Recommendations for Management. Report to the New Hampshire Fish and Game Department Nongame and Endangered Wildlife Program. Audubon Society of New Hampshire, Concord.

MacKenzie, D. I. 2006. Occupancy estimation and modeling: inferring patterns and dynamics of species occurrence. Academic Press.

Mills, A.M. 1986. The influence of moonlight on the behavior of goatsuckers (Camprimulgidae). Auk 103:370-378.

Moller, A. P., Rubolini, D. and E. Lehikoinen. 2008. Populations of migratory bird species that did not show a phenological response to climate change are declining. Proceedings of the National Academy of Sciences of the United States of America 105:16195-16200.

Nebel, S., Mills, A., McCracken, J. D. and P.D Taylor. 2010. Declines of aerial insectivores in North America follow a geographic gradient. Avian Conservation and Ecology 5: 1.

Polgar, C. A., Primack, R. B., Williams, E. H., Stichter, S. and C. Hitchcock. 2013. Climate effects on the flight period of Lycaenid butterflies in Massachusetts. Biological Conservation 160:25-31.

Prugh, L. R., Hodges, K. E., Sinclair, A. R. and J.S. Brashares. 2008. Effect of habitat area and isolation on fragmented animal populations. Proceedings of the National Academy of Sciences 105: 20770-20775.

Raynor G.S. 1941. The nesting habits of the Whip-poor-will. Bird Banding 12:98-104.

Santner, S. 1992. Whip-poor-will. Pages 172-173 in Atlas of breeding birds in Pennsylvania (D.W. Brauning, Editor). University of Pittsburgh Press, Pittsburgh, PA.

Schnell, J. K., Harris, G. M., Pimm, S. L., and G.J. Russell. 2013. Quantitative analysis of forest 
fragmentation in the Atlantic forest reveals more threatened bird species than the current red list. PloS One: 8.

Sibley, S.C. Whip-poor-will. Pages 218-219 in The atlas of breeding birds in New York State (R.F. Andrie, and J.R. Carroll, Editors). Cornell University Press, Ithaca, NY.

Simmonds, I., and K. Keay. 2009. Extraordinary September arctic sea ice reductions and their relationships with storm behavior over 1979-2008. Geophysical Research Letters, 36:19.

Symonds, M. R. and A. Moussalli. 2011. A brief guide to model selection, multimodel inference and model averaging in behavioural ecology using Akaike's information criterion. Behavioral Ecology and Sociobiology 65:13-21.

Tang, Q., Zhang, X., \& Francis, J. A. 2013. Extreme summer weather in northern mid-latitudes linked to a vanishing cryosphere. Nature Climate Change 4:45-50.

United States Department of Agriculture. About the forest. http://www.fs.usda.gov/main/mnf/about-forest (accessed 6 October 2013).

United States Department of Agriculture. Dolly Sods Wilderness. http://www.fs.usda.gov/ recarea/mnf/recreation/recarea/?recid=12366 ( accessed 17 April 2015).

Wilson, M. D. and B.D. Watts. 2006. Effect of moonlight on detection of Whippoorwills: implications for long term monitoring strategies. Journal of Field Ornithology, 77: 207-211.

Wilson, M. D. and B.D. Watts. 2008. Landscape configuration effects on distribution and abundance of whip-poor-wills. The Wilson Journal of Ornithology, 120: 778-783.

Wilson, S. G. 1985. Summer distribution of Whip-poor-wills in Minnesota. Loon 57:6-8. WV State GIS Data Clearinghouse. West Virginia GIS Technical Center. (accessed 18 February 2014). 
Table 1. Ranking of candidate models at $1600 \mathrm{~m}$. Colonization and emigration were held constant and equal in all models an account for 2 of the parameters. The first model with only elevation and edge amount as covariates estimating occupancy has 1.5 times more support than the second model with no covariates. The first model has 3 times more support than the third best model in which elevation, amount of edge, and land cover covariates are used to estimate probability of occupancy. Covariates used in these models are listed in Table 2. When "constant" is listed there was no covariate used to help in estimation of that value.

\begin{tabular}{|c|c|c|c|c|}
\hline Model & QAIC & $\begin{array}{l}\Delta \mathbf{A I} \\
\mathbf{C}\end{array}$ & $\begin{array}{l}\text { AIC } \\
\text { Weigh } \\
t\end{array}$ & $\begin{array}{l}\text { \#Parameter } \\
\text { s }\end{array}$ \\
\hline $\begin{array}{l}\text { Occupancy(elevation+ edge), } \\
\text { detection(year+moon+noise) }\end{array}$ & 458.63 & 0.00 & 0.47 & 10 \\
\hline Occupancy (constant), detection $($ year + moon + noise $)$ & 459.59 & 0.85 & 0.31 & 8 \\
\hline $\begin{array}{l}\text { Occupancy(elevation+edge }+ \text { land cover classes), } \\
\text { detection(year+moon+noise) }\end{array}$ & 467.11 & 2.27 & 0.15 & 15 \\
\hline $\begin{array}{r}\text { Occupancy(land cover classes), } \\
\text { detection(year+moon+noise) }\end{array}$ & 467.51 & 3.84 & 0.07 & 17 \\
\hline Occupancy(constant), detection(constant) & 478.24 & 20.39 & 0.00 & 4 \\
\hline Occupancy(constant), detection(year) & 479.50 & 21.63 & 0.00 & 5 \\
\hline
\end{tabular}


Table 2. Description of the site and sampling covariates used in Table 1 models. The site covariates were used to estimate of probability of occupancy while the sampling covariates were used to estimate probability of detection at locations in Monongahela National Forest (MNF) study area in eastern West Virginia. Program PRESENCE calculated $\beta$ values for each covariate which was then used to help determine percent occupancy and detection given that covariate.

Site Covariates

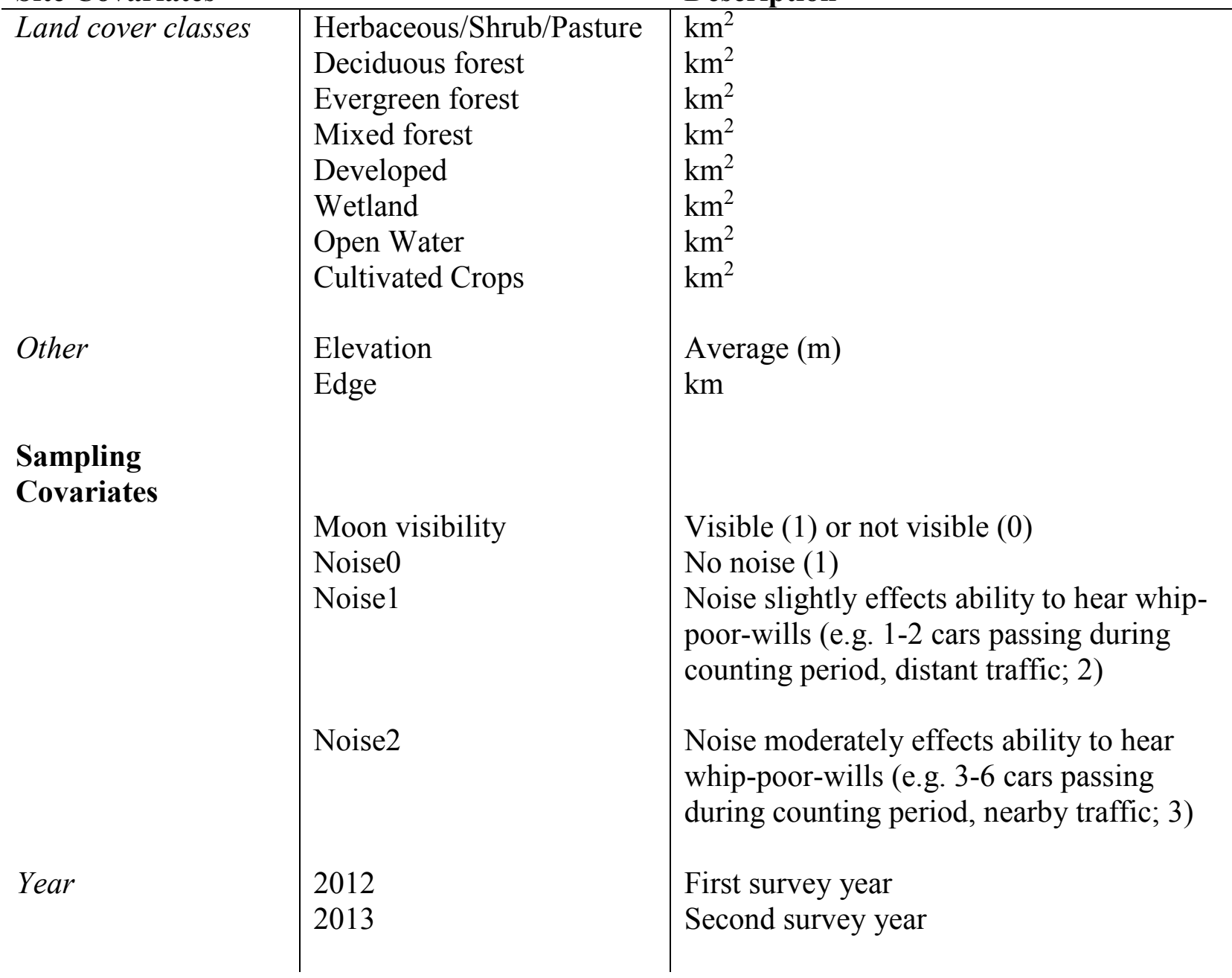


Table 3. Model averaged estimates for occupancy, colonization, emigration, and detection probabilities. Covariate $(\beta)$ estimates and their SEs are untransformed. Percent occupancy, percent colonization, percent emigration, percent detection, the corresponding SEs, as well as the odds ratios are calculated using the beta estimates and associated SEs. Odds ratios indicate how likely an eastern whip-poor-will will be present at, colonize, emigrate, or be detected at an area. For example eastern whip-poor-wills are 8 times as likely to be found when the moon is visible than when it not.

\begin{tabular}{l|cc|cc|c}
\multicolumn{1}{c|}{ Parameter } & Beta Estimate & SE & \% & SE & $\begin{array}{c}\text { Odds } \\
\text { Ratio }\end{array}$ \\
\hline Occupancy (Deciduous & 1.30 & 1.47 & 0.79 & 0.25 & 3.67 \\
Forest) & 0.68 & 0.18 & 0.66 & 0.04 & 1.97 \\
Occupancy (MixedForest) & 0.57 & 0.11 & 0.64 & 0.03 & 1.77 \\
Occupancy & -0.10 & 0.24 & 0.48 & 0.06 & 0.90 \\
(Herbaceous/Shrub/Pasture) & -0.18 & 0.04 & 0.46 & 0.01 & 0.84 \\
Occupancy (Edge) & -0.40 & 0.05 & 0.40 & 0.01 & 0.67 \\
Occupancy (Wetlands) & -0.67 & 0.27 & 0.34 & 0.06 & 0.51 \\
Occupancy (CultivatedCrops) & -0.70 & 0.29 & 0.33 & 0.06 & 0.50 \\
Occupancy (EvergreenForest) & -1.11 & 0.42 & 0.25 & 0.08 & 0.33 \\
Occupancy (Developed) & -1.64 & 0.27 & 0.16 & 0.04 & 0.19 \\
Occupancy (Elevation) & -4.78 & 2.64 & 0.01 & 0.02 & 0.01 \\
Occupancy (Open Water) & -1.32 & 0.84 & 0.21 & 0.14 & 0.27 \\
\hline Colonization & 2.08 & 1.01 & 0.89 & 0.10 & 8.00 \\
\hline Emigration & -0.21 & 0.26 & 0.45 & 0.06 & 0.81 \\
\hline Detection (Moon Visibility) & -0.23 & 0.09 & 0.44 & 0.02 & 0.79 \\
Detection (2013) & -0.67 & 0.47 & 0.34 & 0.11 & 0.51 \\
Detection(Noise 0) & -1.50 & 0.88 & 0.18 & 0.13 & 0.22 \\
Detection (2012) & -2.90 & 1.61 & 0.05 & 0.08 & 0.06 \\
Detection (Noise 1) & & & & & \\
Detection (Noise 2 ) & & & &
\end{tabular}




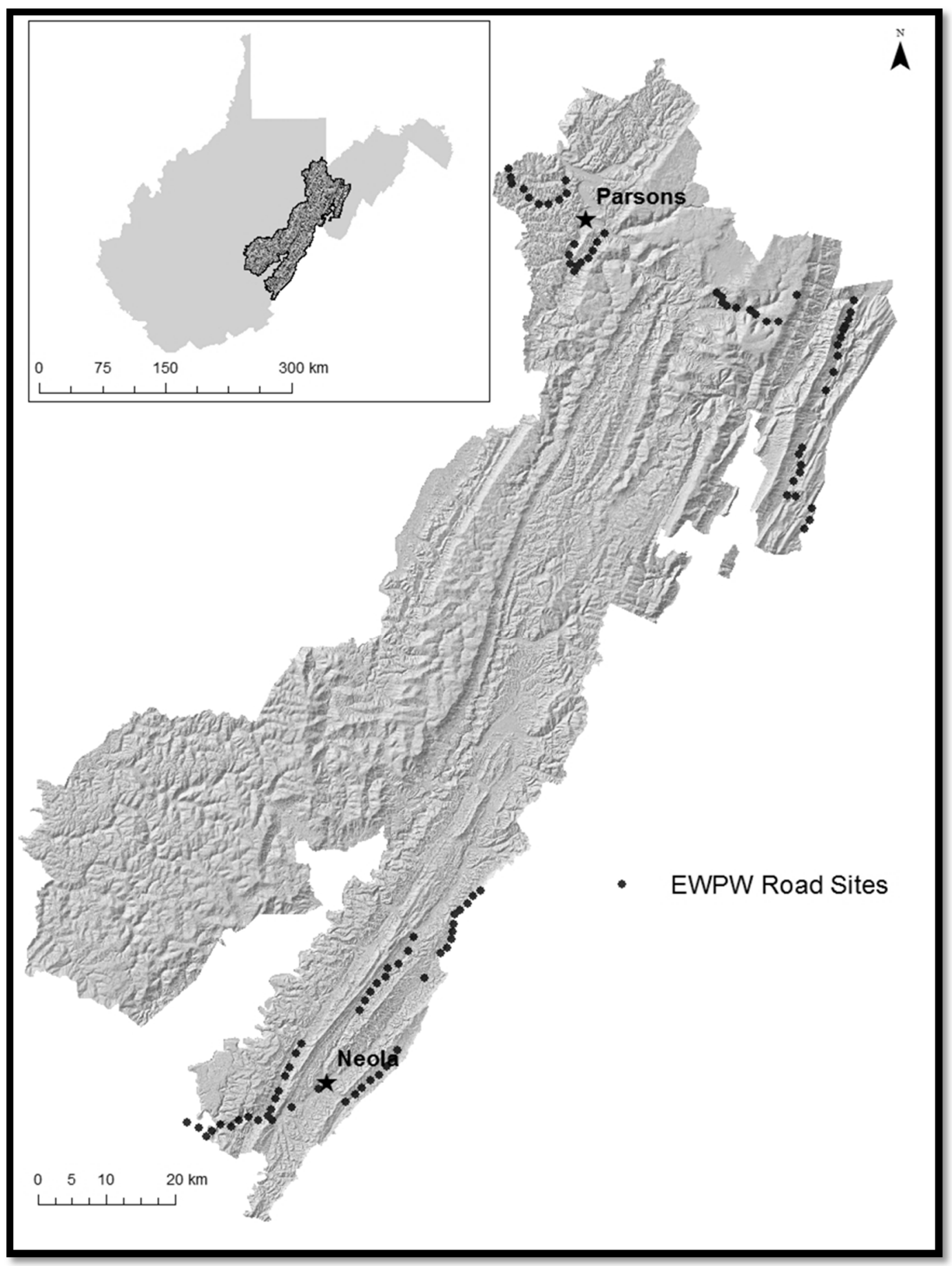

FIG. 1. Greyscale topographic relief of the Monongahela National Forest (MNF) study area in eastern West Virginia. Nocturnal surveys of eastern whip-poor-wills (EWPW) were conducted at 95 points along 10 roads. The towns of Neola and Parsons WV are shown with a star and the inset shows the location of the MNF within West Virginia. 


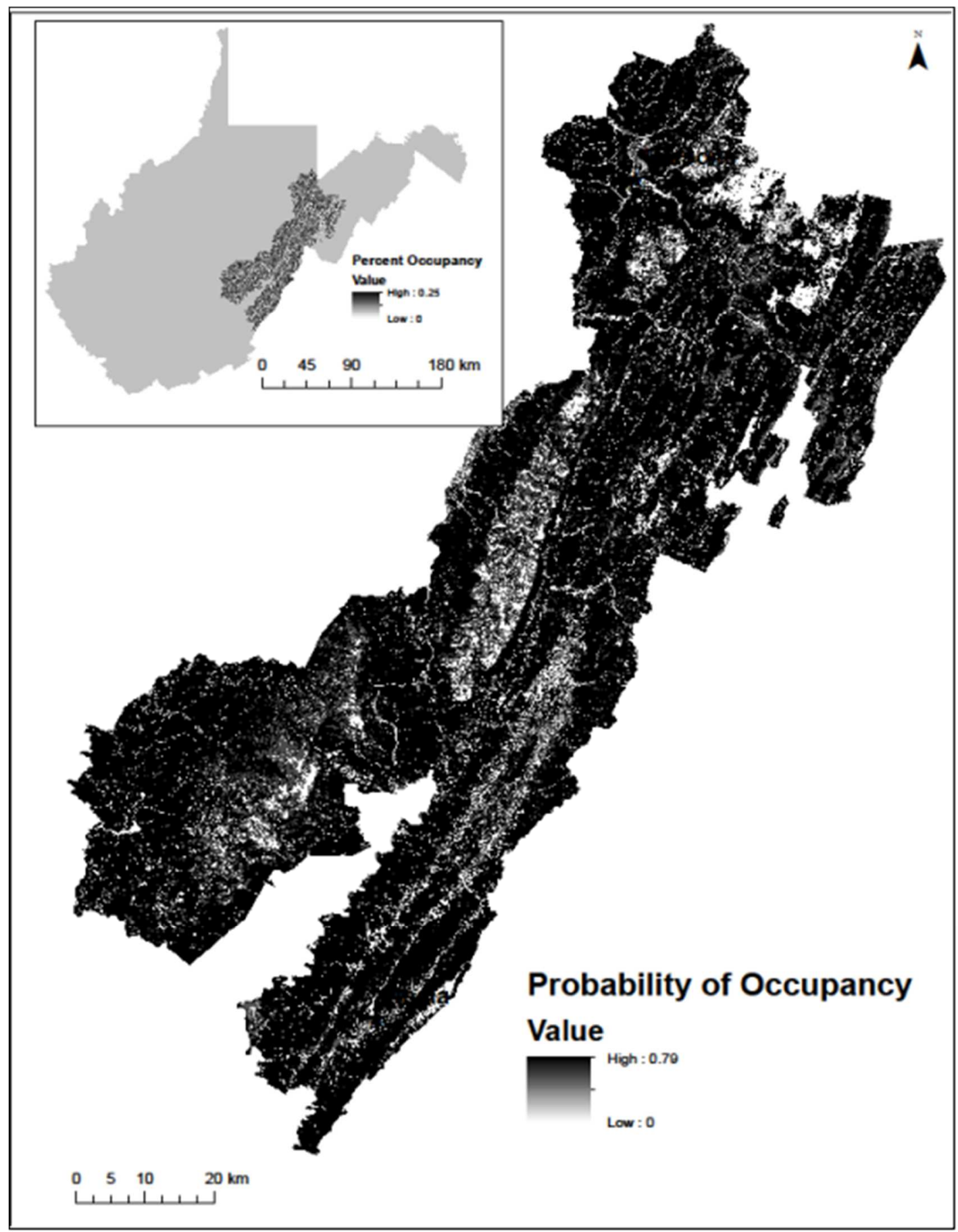


FIG. 2. Probability of eastern whip-poor-will occupying an area of the MNF given land cover type present and raster data from NLCD 2006 land cover data in West Virginia. Areas where whip-poor-wills are likely to be found based on land cover are darkly colored while areas where they are not likely are light in color. The inset map portrays the location of the MNF within West Virginia as well as eastern whip-poor-will occupancy based on elevation and edge raster data alone. As in the larger map, areas that are more darkly colored indicate areas with estimated higher probabilities of occupancy. 
Appendix A. This appendix includes our classifications of land cover based on 2006 USGS land cover classifications. The descriptions of the USGS classifications can be found at the Multi- Resolution Land Characteristics Consortium webpage. The open water and shrub/scrub were eliminated since there was very little area under those classifications in our study.

\begin{tabular}{|l|l|l|}
\hline $\begin{array}{l}\text { NLCD Land Cover } \\
\text { Classifications }\end{array}$ & $\begin{array}{l}\text { Corresponding Land Cover } \\
\text { Classes }\end{array}$ & $\begin{array}{l}\text { Nesting or Foraging } \\
\text { Habitat }\end{array}$ \\
\hline Open Water & Open water & NA \\
Developed, Open Space & Developed & Foraging \\
Developed, Low intensity & Developed & Foraging \\
Developed, Medium Intensity & Developed & Foraging \\
Developed, High intensity & Developed & Foraging \\
Deciduous Forest & Deciduous Forest & Nesting \\
Evergreen Forest & Evergreen Forest & Nesting \\
Mixed forest & Mixed forest & Nesting \\
Shrub/Scrub & Herbaceous/Shrub/Pasture & Not used \\
Grassland/Herbaceous & Herbaceous/Shrub/Pasture & Foraging \\
Sedge/Herbaceous & Herbaceous/Shrub/Pasture & Foraging \\
Pasture/Hay & Herbaceous/Shrub/Pasture & Foraging \\
Cultivated Crops & Cultivated Crops & Foraging \\
Woody Wetlands & Wetland & Foraging \\
Emergent Herbaceous Wetlands & Wetland & Foraging \\
\hline
\end{tabular}

